\begin{tabular}{l|l}
$\mathbf{m}$ & south \\
n & asia
\end{tabular}

samaj

uilu academic
South Asia Multidisciplinary Academic Journal

17 | 2018

Through the Lens of the Law: Court Cases and Social Issues in India

\title{
A Chronicle of Law Implementation in Environmental Conflicts: The Case of Kaziranga National Park in Assam (North-East India)
}

Joëlle Smadja

\section{(2) OpenEdition}

\section{Journals}

Electronic version

URL: http://journals.openedition.org/samaj/4422

DOI: $10.4000 /$ samaj.4422

ISSN: 1960-6060

Publisher

Association pour la recherche sur l'Asie du Sud (ARAS)

Electronic reference

Joëlle Smadja, «A Chronicle of Law Implementation in Environmental Conflicts: The Case of Kaziranga National Park in Assam (North-East India) », South Asia Multidisciplinary Academic Journal [Online], 17 | 2018, Online since 17 November 2017, connection on 19 April 2019. URL : http:// journals.openedition.org/samaj/4422 ; DOI : 10.4000/samaj.4422

This text was automatically generated on 19 April 2019

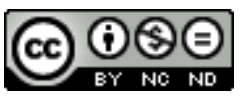

This work is licensed under a Creative Commons Attribution-NonCommercial-NoDerivatives 4.0 International License. 


\title{
A Chronicle of Law Implementation in Environmental Conflicts: The Case of Kaziranga National Park in Assam (North-East India)
}

\author{
Joëlle Smadja
}

The Kaziranga Tiger Reserve notification should be withdrawn. Instead of Tiger Project, Rhino Project only should be implemented in Kaziranga National

Park. Kaziranga is famous for the one-horned rhino not for tiger. We want to protect only rhino

(Kaziranga Eco-Sensitive Zone 2015). ${ }^{1}$

It is with these words that villagers living in the area surrounding Kaziranga National Park (KNP) often give voice to their revolt. This Park, which is the pride of the State of Assam for its one-horned rhinoceros and its nature-protection "success story," has become a political arena over the last ten years, a space where numerous conflicts have crystallized. Successive extensions to its perimeter, accompanied by restrictive measures, have led to greater and greater tension, and its 2007 inclusion in Project Tiger-an Indian government project aimed at increasing the number of tigers in the country ${ }^{2}-$ has merely intensified it. The protection of rhinos from poaching and the eviction of populations from the Park's perimeter have turned into electoral issues-they feature in political party manifestos-, and nature protection is being used for purposes that do not always have anything to do with environmental concerns. These conflicts are not short of symbols or a scapegoat: the rhinoceros, a symbol of the State of Assam and of an "untouched" nature that needs to be protected; the tiger, an intruder for the people living around the park, a symbol of the Indian central government and a "foreigner"; and the Muslim Bangladeshi migrant accused by some conservationists of being an encroacher and a poacher, the source of all ills. 
2 In a bitter struggle, environmentalists or activists, demanding measures to protect nature and voicing the rights of wild animals-they demand the complete removal of poachers and the eviction of "encroachers"-, oppose farmers whose very survival is being threatened by damage caused by wildlife and who, under the Park's legislation, have become "outlaws." This struggle is turning more and more to the law courts in a process that could be called the judicialization of nature or the judicialization of environmental disputes (cf. Commaille et al. 2010; Berti and Tarabout 2015; etc.). Though this process can be observed throughout the world, it takes on special importance in India, due in part to the relative ease with which people can apply directly to courts of appeal, notably via PILs (Public Interest Litigations) that were introduced in $1979^{3}$ and which, moreover, have helped to develop judicial activism: judges can take initiatives and thus become defenders and promoters of environmental or ecological values (cf. Berti 2015).

It so happens that I started working in this area in 2006 at a turning point when the protected area was extended, when conflicts were on the rise and were increasingly militarized and judicialized; when decision-making bodies with extensive powers, environmental legislation and nature-protection or population-defense organizations emerged: in 2005, the Right To Information Act (RTI), and the same year the setting up of a branch of KMSS (Krishak Mukti Sangram Samiti: Freedom for Farmers Committee) in the region; in 2006, the Forest Rights Act (FRA 2006) ${ }^{4}$ and Project Tiger (implemented in 2007 in KNP) along with its decision-making body, the National Tiger Conservation Authority (NTCA); in 2010 the creation of the National Green Tribunal (NGT); also in 2010, a key amendment made to the Wildlife (Protection) Act 1972 (WPA 1972) which in Assam grants more power to foresters. Over the years these measures have all contributed to defining the new forms these conflicts have taken.

4 The chronology of the facts presented here for the local example of Kaziranga National Park sets out to show some of the workings of nature's protection policy in India, and notably the effects of an escalation in administrative and legal measures which, in a never-ending spiral, outbid each other for positions that, as far as the populations are concerned, are more and more radical. Through the lens of environmental law in the making, it highlights the combination of ecological, social, political, cultural and symbolic features which are well-known components of environmental issues.

It emerges from this study that the measures intended to protect the poorest populations -and which were seen as democratic advances in India-have either not been enforced, which is the case of FRA 2006, or have been misappropriated by the elites, for whom environmental issues do not seem to have always been the main motivation here. This is the case of PILs which are now used for completely different purposes than originally intended (see Sen 2015; Sivaramakrishnan 2011; Vaidya 2016, etc.). As for the measures and the pieces of legislation introduced over the years to protect nature, they all reinforce the power of the forestry corps. These findings raise questions about the role of courts of law in government policy, about their power with regard to States, about "the expression of law and its role in the management of environmental crises" (Michelot 2006:119). 


\section{The context of a conflictual situation and the way it is addressed}

6 Access to land is the source of most of the conflicts in Assam. It gives rise to antiimmigration battles and to territorial autonomy claims. For economic and political reasons there have always been large numbers of immigrants in this Indian State. During the nineteenth century, successive waves of Indians from Orissa, Jharkand, Chattisgarh and South India arrived there to be employed by the British on tea plantations, while other Indians came from Bihar to take up work in the fishing or river navigation sector, and others from Rajasthan in trade. Nepalese immigrants were also employed on tea plantations and thousands of Nepalese practicing cattle breeding arrived during the first part of the twentieth century. After the Partition between India and Pakistan in 1947 many people from East Pakistan (now Bangladesh) went to Assam looking for land and employment; this trend intensified after the 1970s (the population density in Bangladesh is currently more than 1,000 inhabitants per square kilometer, while in Assam it is 400). Parallel to or in connection with these migrations, claims to autonomy have shaken Assam. Since the 1970s several ethnic groups have been granted territorial autonomy (the Karbis, Bodos). Others who already have their own autonomous councils, such as the Misings, Tiwas, Thengal-Kacharis, Deuris, etc. are now demanding their own autonomous districts. Tea workers, also called "Tea Tribes", have also embraced these claims demanding at the same time the status of Scheduled Tribe. ${ }^{5}$ As for the United Liberation Front of Assam (ULFA), it has been fighting an armed struggle for the total independence of Assam and advocating the exclusion of migrants. Let us also bear in mind that the State of Assam is one of the least developed Indian States, and is relatively isolated from the rest of the country. Issues related to environmental protection in Kaziranga National Park need to be situated in this context.

7 Kaziranga National Park is located in central Assam, along the Brahmaputra River. It is a very densely populated area (about 500 inhabitants per square kilometer), with approximately 50,000 farms surrounding the Park. The people there live off agriculture, cattle breeding and fishing, and some of these activities are practiced on ephemeral shifting islands in the bed of the Brahmaputra River. These islands, called saporis in Assam, become flooded during the monsoon season. They are occupied by riverine populations in the dry season, mostly by Misings, ${ }^{6}$ a Scheduled Tribe originally from Arunachal Pradesh, by Biharis and by Nepalis who are mainly herders. Before the next floods come, they cultivate grains or vegetables on these islands. And for domestic or commercial purposes they collect branches that are used as firewood or for roofing. They graze buffaloes that are reared for dairy produce; they fish in ponds and in the arms of the river. Far from being unproductive, barren, uninhabited deserts, these islands are used by populations that are highly adapted to this shifting environment and who were once very mobile themselves. Each year the Brahmaputra floods wash away land belonging to both farmers and to the National Park. The growing population and the landless are forever making claims over land. As for the Park, where the protection of wildlife is proving to be a success, it is claiming more and more land because elephants, rhinoceroses, and now tigers too-whose number has increased and has been left unchecked-do not have enough space (Smadja 2013). Kaziranga hosts two-thirds of the world's great one-horned rhinos-there were around forty in 1905, one thousand eight 
hundred and fifty-five in 2006 and two thousand four hundred and one in 2015-, and the highest density of tigers among the world's protected areas (thirty tigers per hundred square kilometers). The Park also has large breeding populations of elephants, water buffalo and swamp deer.

The data presented here are partly the result of surveys conducted within two research programs between 2006 and 2013. ${ }^{7}$ This text is based on an examination of the two main forces that drive the key figures in these conflicts.

The first force is the fight over territory between the population and the wildlife that has to be protected. It concerns in part what is commonly called a "human-wildlife conflict" and is about the destruction caused by wildlife and compensation for this. In this case, disputes are not brought before the court but the main legislative tool is called upon to settle these matters: the Wildlife (Protection) Act 1972. This fight over territory is also expressed through an expansionist nature policy that consists in expanding the Park's perimeter and in evicting people from it; in this case the number of lawsuits is on the rise. The second driving force is the fight to put a stop to poaching. A large administrative and legal arsenal has consequently been deployed involving a large number of stakeholders.

The text is also based on three main pro-nature protection complaints that have orchestrated the way in which the situation has evolved: a PIL filed by an activist belonging to right-wing Hindu nationalist movements, together with a suo moto PIL filed by Gauhati High Court and another one by an inhabitant of the Kaziranga NP area following a series of questions under the Right To Information. It also relies on a writ petition filed by the villagers who are to be evicted; this helps us to assess the application or non-application of administrative decisions and laws, how they are used-this is particularly the case of FRA 2006.

\section{A fight over territory}

\section{A "human-wildlife conflict" or administrative and political choices?}

It is precisely when thinking and formulating the determining interactions that social groups, both in their political and technical or scientific discourse, build an appropriate vocabulary. The crisis exists above all and especially through its semantic expressions ${ }^{8}$ (Beck et al. 2006:405).

The National Park's growing number of wild animals, which are well protected, comes with a downside since these animals venture outside the park perimeter, instilling fear, causing injury to farmers and damaging crops and cattle. Indeed, hordes of elephants (which may comprise more than a hundred animals) and rhinoceroses regularly destroy crops, homes and sometimes kill people, while tigers frighten populations and kill cattle. It is possible to count the number of persons killed, the houses and hectares of crops destroyed, the elephants and rhinos killed in their hundreds. ${ }^{9}$ This tragic situation has worsened from one year to the next. In fact, the Park and its surrounding area are like a battlefield where the victims can be counted on both sides (cf. Smadja 2013).

This fight is commonly called a "human-wildlife conflict." It is not limited to Kaziranga National Park. Hundreds of people and at least fifty elephants are killed every year in India (Thakur 2015a), and big cat attacks regularly make the Indian headlines.

People are not aware of their basic rights regarding damage caused by wildlife to crops, property, cattle and persons. They do not even know what to do or whom to contact 
when they fall victim of this. Most NGOs, of which there is a relatively large number in the area, work towards Nature Conservation, Wildlife Welfare, etc.; none or very few of these help people to defend their rights. Very often the first person these victims turn to is a journalist who helps them to fill in administrative forms; the latter is a real-if not the only-social actor in the area. People do not demand their rights before a Court of law: they fear the latter and do not have enough money to pay for a lawyer. They simply contact the Forest Department which up until 1992 was in charge of making enquiries. But there have been so many cases of abuse and corruption that since then a mandal, a circle officer, has been appointed to verify the facts. He reports to the Revenue Office. His report is sent to the Deputy Commissioner who decides, on a somewhat flexible basis, the amount of money people should receive as compensation. As far as crops are concerned, people obtain hardly any compensation. They are supposed to receive between 1,000 and 2,000 Indian rupees ${ }^{10}$ for a house that has been destroyed by an elephant. Many of them are still waiting for this amount. If a person is killed by an elephant, their family should get 1 lack $(100,000)$ of Indian rupees. They rarely receive this amount and most people have been waiting years for a financial settlement. As for cattle killed by a tiger, this is another tricky situation since proof has to be established that it was indeed a tiger that killed the animal, because any compensation is given via Project Tiger. As a consequence, very detailed observations and measures, particularly of pug marks, are carried out to establish the origin of the damage. When cattle are killed, farmers receive INR 2,500 from the Forest Department long after the event and on condition that the farm is located outside the Park's additions. In light of farmers' outrage at this, WWF now doubles this amount within an Interim Relief Program. Nevertheless, the price of a cow or bullock to replace the one killed ranges between INR 12,000 and 15,000. Some farmers have therefore stopped cultivating their land because they no longer have a bullock to plough it.

In fact, the process of obtaining compensation is very similar to the one described by Nayanika Mathur (2014) regarding the situation in Gopeshwar (Uttarakhand). Inertia, difficulties, misunderstandings are the overall outcome of this type of approach for victims who ultimately receive only meagre compensation when they do obtain any at all (Mathur 2014:161).

"conflict" is generally attributed to a recent reduction in the space earmarked for wildlife. However, several historical texts testify to the fact that during the pre-colonial period there were already frequent encounters between peasants and wild animals as agrarian lands spread... (Saikia 2005:254): in 1835, Captain Jenkins wrote,

of wild animals we have herds of every species, elephants, rhinoceros, buffaloes, tigers, leopards, jackals, and numerous kinds of monkeys. They all commit serious depredations on the crops, and more particularly the elephants, which often demolish granaries in the open day to get at the grain and salt (Saikia 2005:254).

Numerous reports testify to the number of people and cattle killed by wildlife and to the serious damage they cause to crops. None of today's problems are therefore new. What has changed, however, is that whereas British rulers offered a prize for killing wild animals at the end of the nineteenth century with the aim of extending agricultural areas -this was followed by agricultural land being made available on a large scale in the 1930s and 1940s (Saikia 2005:256) -, ever since 1950 numerous laws have been enacted to protect wildlife which was indeed in danger, the most important of these being the Wildlife (Protection) Act 1972 and its subsequent amendments. In this Act wildlife is classed into five "Schedules" and a ban on hunting applies to the first four Schedules, 
with the fifth one corresponding to "vermin" which can therefore be hunted. Although animals from Schedule III and IV may be declassified if required as an exceptional measure and moved to Schedule $\mathrm{V}$, this is not the case for animals in Schedule I to which tigers, elephants and rhinoceroses belong. The penalty for killing an animal from Schedule I, according to the Wildlife (Protection) Act 1972, is three years' imprisonment which may extend to seven years, with a minimum fine of INR 10,000.

Some of the problems stem from this total ban on hunting because the number of wild animals is not regulated, and they can cause serious damage for which there is no compensation.

Although this "human-wildlife conflict" is being played out only at an administrative level in Assam and has not been brought before the court, due to a worsening situation in the country discussions about it have begun at the government level, especially in view of modifying the Wildlife (Protection) Act 1972. Thus, on 24 February 2015, when members of Lok Sabha asked the representative of the Ministry of Environment and Forests: "Whether the Government has issued directions to the State Governments to formulate their own policies to deal with the increasing human-wildlife conflict around over 650 wildlife zones in the country" (Tigernet 2015a), the response was as follows:

The human-wildlife conflict is a serious issue affecting the lives of people. Though, the Wildlife (Protection) Act, 1972 generally prohibits hunting of the specified wild animals, it also has provisions relevant to deal with situations of human-wildlife conflict. It was felt that the officers empowered by the Wildlife (Protection) Act, 1972, in this context, were not exercising their powers sufficiently. Therefore, the Ministry has issued an advisory to the Chief Wildlife Wardens of all the States/ Union Territories, apprising them about legal provisions in the Act, to deal with the situations of human-wildlife conflict, and also listing of animals under Schedule $\mathrm{V}$ (Vermin) in case one or more of the animals are assessed to be necessary for listing therein. Ministry has advised them to exercise the powers granted under Section 11 (1)(b) of the Act empowering them to authorize hunting of identified animals in certain situations (Tigernet 2015a).

In other discussions, the Ministry also acknowledges the loss of crops due to damage caused by wild animals (Tigernet 2015b). However, these discussions mainly concern animals such as the Nilgai and Wild boar which are classed as Schedule III and may be declassified and therefore hunted. But the conflict is mainly about tigers, rhinos and elephants which cannot be declassified: hunting them remains totally prohibited. Even if they kill people the situation is extremely complicated, as clearly demonstrated by Nayanika Mathur (2014) in Gopeshwar, who shows how it takes an inordinate amount of time to obtain authorization to kill a "man-eating" big cat, which allows time for the same animal to kill several more people before authorization to hunt it is granted. As for compensation, whether in Gopeshwar or in the area surrounding Kaziranga, it is difficult to obtain any: it is a long-winded process and it ultimately barely covers the damage caused. The statements in the petition that the population of Gopeshwar addressed to the Chief Minister of Uttarakhand are the same as those that can be heard around Kaziranga: "The state has today put the worth of a leopard greater than the worth of humans. Is there no value left to humans in Indian democracy today?" (Mathur 2014:159).

21 Foresters and the Park administration attribute this "human-wildlife conflict" to a shortage of space for wildlife. When discussing this with them they often refer to the fact that we humans live on a territory that belongs to rhinos, tigers and elephants, and they 
try to get people to recognize this during nature protection training sessions. Therefore, one of their solutions to solve the problem is to extend the protected area.

Photo 1

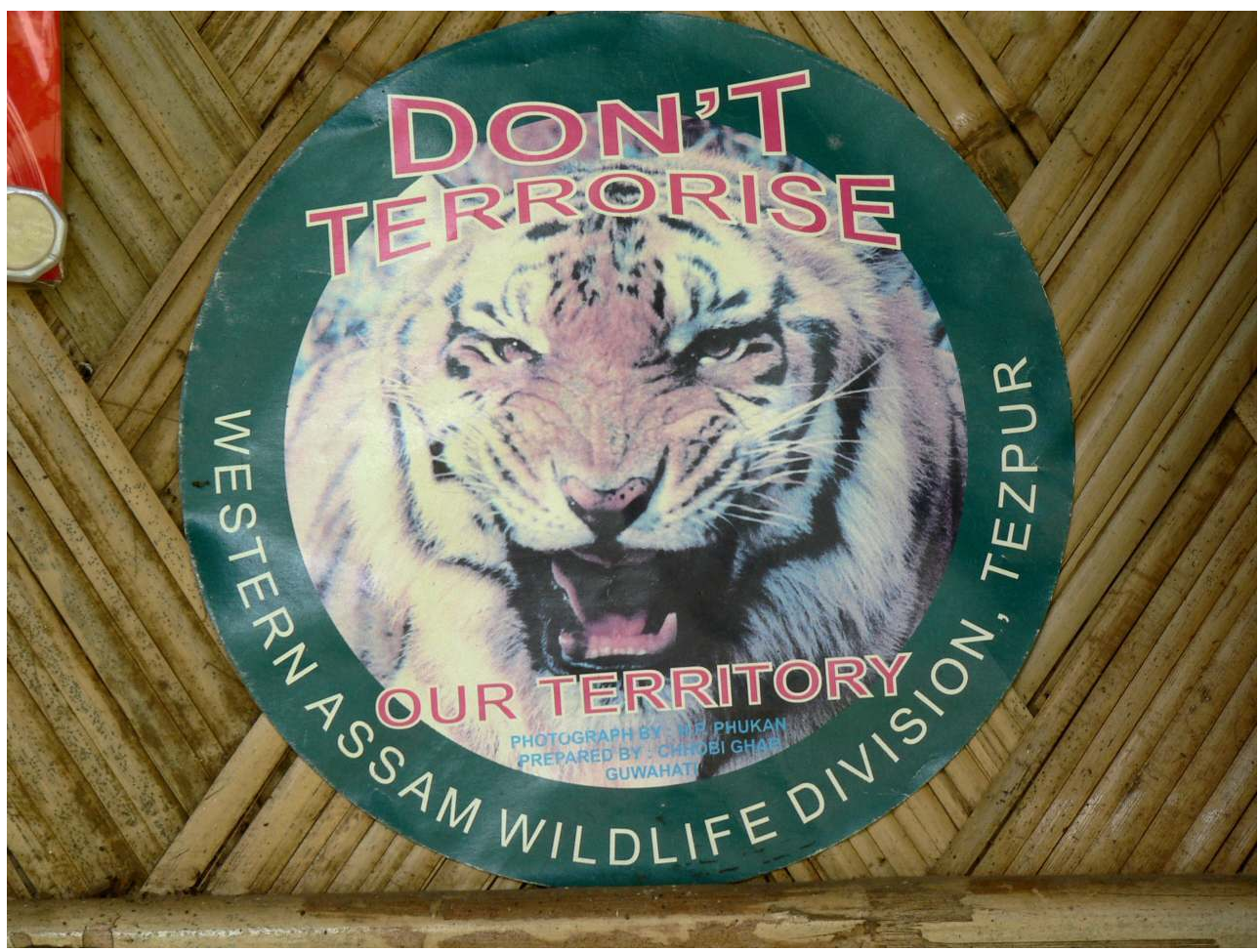

PICTURE FROM WWF ILLUSTRATINg THE POINT OF VIEW OF THOSE SEEKINg TO PROTECT TIgERS.

PHOTO J. SMADJA, MARCH 2007

\section{Requalifying space: An expansionary policy of nature conservation}

Since 1905 when the British turned Kaziranga area into a reserved forest to protect rhinos and to pursue their hunting activities (at the time rhinos were on the verge of extinction because of big game parties), the boundaries of the protected area have been repeatedly pushed back (see Smadja 2013). It became a Game Reserve in 1916 where hunting continued until 1948. At this date the one-horned rhino became the State symbol of Assam. The reserve was converted into a wildlife sanctuary in 1950. Then in 1974, to ensure better protection of wildlife, it became a national park which underwent six extensions between 1977 and 1999, doubling its original surface area (from 434 to $884 \mathrm{~km}^{2}$ ). Saporis, the ephemeral shifting islands, are now included within the Park's perimeter. A seventh extension is scheduled to include the surrounding hills so that corridors can be created to allow wildlife to circulate and to find shelter during the monsoon. In 1985 the Park was inscribed on the UNESCO World Heritage List under criteria (x) because it houses the biggest one-horned rhinoceros population in the world and under criteria (ix) because it is said to be "an example of a still virgin flood plain and grass ecosystem" (UNESCO N.d.). It was subsequently recognized as an important area for bird conservation by Birdlife International. Since 2007 it has become part of the Indian National Project Tiger; it has undergone other extensions and has now been declared a Tiger Reserve. ${ }^{11}$ 

divided and subjected to new regulations. Each subdivision comes with new classifications. In addition to new spatial entities such as the National Park, the tiger reserve, and their corollaries-core area, buffer area and animal corridors-, a "no development zone" was set up in 1996 around Numaligarh Refinery ${ }^{12}$ within a 15kilometer radius, followed by an "Eco-Sensitive Zone" project in 2015. All these spatial subdivisions have drawn new boundaries each of which redefines the rights and duties of the people.

Since the creation of the protected area and its successive extensions, thousands of people have been displaced. Only those holding property titles have been granted new land outside the park, though often where they are unable to pursue their activities. Those who have refused to move, as well as the landless, have remained in some sectors illegally. Many of them have survived so far thanks to resources they find on the saporis. Since these islands now also fall within the park's perimeter, all these villagers are considered outlaws, encroachers and some of them have become poachers.

\section{Photo 2}

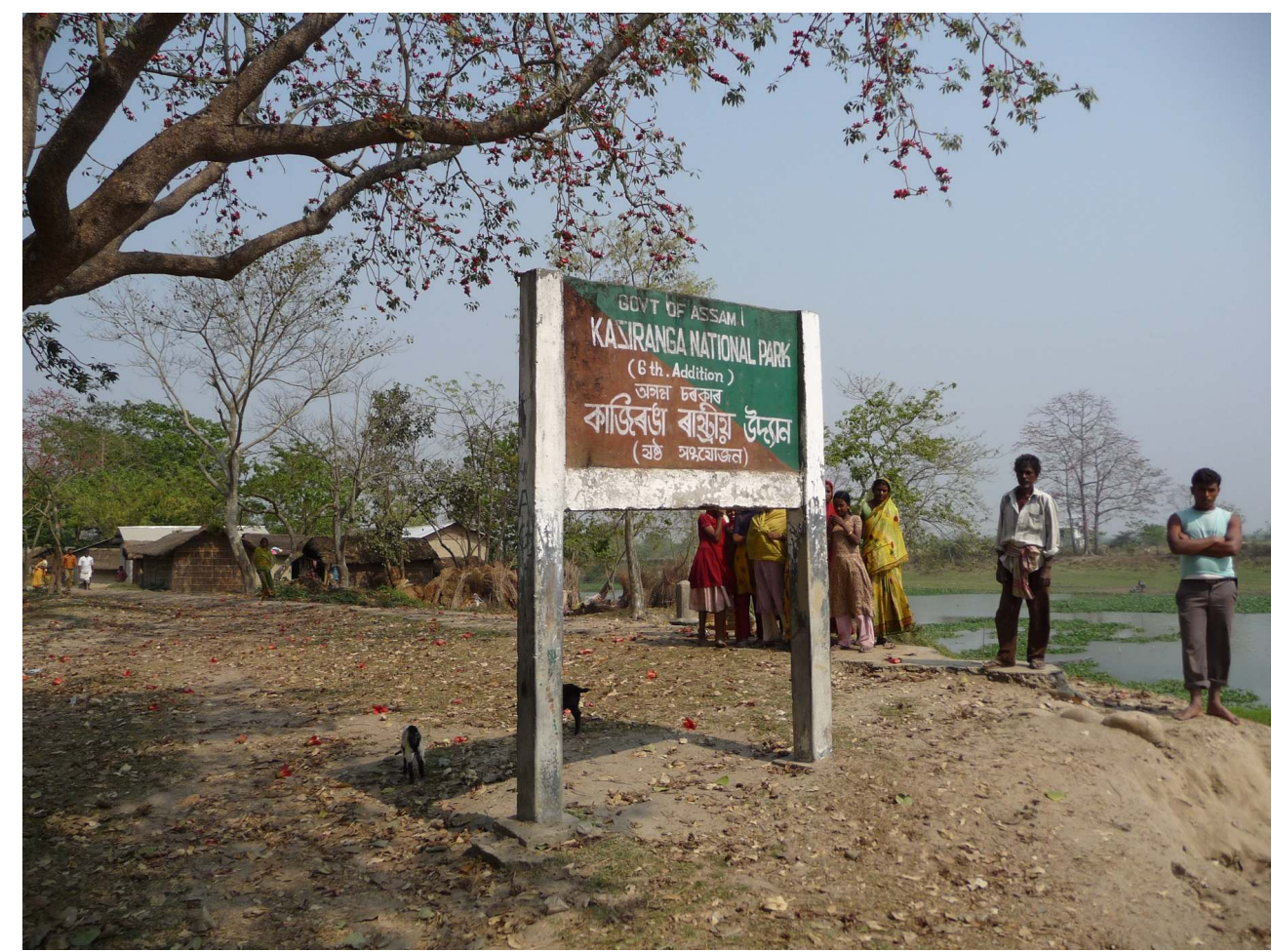

SIgN INDICATING THE PARK'S NEW LIMIT. PEOPLE STAYING WITHIN THIS LIMIT ARE NOW OUTLAWS.

PHOTO J. SMADJA, FEB. 2009

Since 1972 this has been the situation throughout India. Kumar and Kerr recall that the strict application of the Wildlife (Protection) Act 1972 criminalized livelihoods and contributed to the marginalization of millions of forest dwellers: "The forest bureaucracy treats the presence of forest dwellers on legal forest lands as encroachments and officially seeks to evict them" (Kumar and Kerr 2012:755). ${ }^{13}$ Sarah Benabou's work related to the Nanda Devi biosphere reserve in Uttarakhand also illustrates this issue (Benabou $2012 a, b)$.

South Asia Multidisciplinary Academic Journal, 17 | 2018 
26 In actual fact, this situation is not new in Kaziranga: the entire history of Kaziranga is one of evicting populations and of fights over land. Between 1905 and 1950 a hundred households-six villages in all-were evicted. At the time these extensions gave rise to numerous protestations. Arupjyoti Saikia reports that:

In 1924, a large number of peasants from the neighborhood of the sanctuary, through a petition signed by several hundred peasants, strongly protested against the very idea of the creation of a reserve exclusively meant for animals and demanded that they be allowed land for cultivation. They argued that this had emerged as a major threat to their agricultural practices (Saikia 2005:274).

Likewise, at the beginning of the 1970s, when the decision to set up the National Park was taken, one forester recalls:

Most people across the state welcomed the move but those living on the fringe areas of the proposed park expressed their vehement opposition to it ... Fishermen and graziers were the most concerned ... The divisional forest officer had a tough time convincing the people in the vicinity to give up their dependence on the rhino homeland ... Our biggest problem was to tell the people that they could no longer go into the forest for collecting firewood or catch fish since Kaziranga was set to become a National Park ... People simply could not understand that Kaziranga was to become a prohibited area aimed at protecting the wildlife in general and the rhino in particular ... It took us more than four years to get across to them fully, but once they were convinced, I must say they fully cooperated with us (Gokhale and Kashyap 2005:29).

Today's clashes show that this is not the case and, although the idea of the Park has been more or less accepted, this has not been the case of its additions. So far only the first and fourth additions have actually been made; the other four are sources of conflict. In the case of the 6th addition, it is a question of people-mostly Biharis and Nepalis-asserting their rights as herders on this land which they do not own but on which they have been paying pasture taxes (touzi bahi revenue) since the 1920s. Following the decision in 1986 to make the 6th addition and after the first clashes with the Forest Department, graziers filed an official complaint with Gauhati High Court. A status quo allowed them to stay on this land until 2009, despite several new developments at the High-Court level and attempts by the Forest Department to evict them by setting fire to their shelters.

\section{PIL and FRA 2006: measures that were to constitute democratic advances}

As far as Kaziranga is concerned, the first thing that had some bearing on this dispute was the fact that Krishak Mukti Sangram Samiti (KMSS) settled in the region in 2005 and that the Forest Rights Act was passed in 2006. KMSS federated the struggles of the people who were to be evicted and helped them to formulate their complaints and demand their rights under FRA 2006. ${ }^{14}$ Since 2006, other groups of herders have filed written petitions, including Nepalis and Biharis, and also Assamese. When they demand their rights within the framework of FRA 2006, these farmers have to prove they have been occupying the land they claim as their own for 75 years; this is very difficult in Assam where most of the population living along the Brahmaputra has been displaced by the 1950 earthquake and by annual floods. Moreover, in 2009, following the Forest Department's position, Gauhati High Court ruled that historically no forest-dwelling communities exist in Assam and hence petitioners demanding their rights via the FRA should be regarded as encroachers, which according to the lawyers who worked on drawing up the FRA is a very biased way of interpreting it (cf. Sarma 2012:506). Today neither scheduled tribes, nor any other forest dwellers have any rights in Assam under FRA 2006. 

field of environmental protection, two PILs have contributed to changing the situation. One of them was filed at Gauhati High Court in 2012 (PIL 67/12, Gauhati High Court 2015) by an inhabitant of the area surrounding Kaziranga who is a Hindu nationalist activist. This PIL aims at getting people evicted from the additions to the Park to protect wildlife more effectively. It argues that the populations currently living on this land are encroachers, that some of them are illegal Bangladeshi migrants and that these people are poachers or that they protect poachers who kill rhinos for their horns: whatever the case, they are outlaws. The second PIL, which was concomitant with it, was a suo moto PIL filed by Gauhati High Court: it also seeks to have these additions cleared to limit poaching and to protect wildlife (PIL 66/12, Gauhati High Court 2015).

January 2013, based on these PILs, Gauhati High Court directed the Assam Government to evict encroachers from the additions to KNP within three months. The PILs that led to this decision raise the question of who the "public" in these PILs is today (see Vaidya 2016 quoting Gauri 2014). The number of PILs has skyrocketed in India. However, unlike at the beginning when they were undertaken to defend people's rights, a number of them are now filed for environmental protection reasons and, as we can see here, even in the name of wildlife protection. Indeed, PILs were initially introduced to "devise new procedures which would make it easier for the disadvantaged to use the legal process and evolve new, equitable principles oriented to distributive justice" (Justice Bhagwati 1985:570 quoted by Sen 2015:29); or else, as Sivaramakrishnan puts it, "we can think of the ... early 1980 s as a period when the PIL was used as a tool of social justiceaddressing mostly cases about abolishing bonded labor, establishing workers' rights, enforcing the rights of prisoners to legal representation, and consolidating women's rights" (Sivaramakrishnan 2011:914-15). On the contrary, as Vaidya explains, quoting Gauri (2014), "the 'public' of Public Interest Litigation shifted in the 1990s from subalterns to the elite. Through the late 1980s, PIL claimants from disadvantaged groups ... had a higher rate of winning their cases than claimants from forward castes. The Court's reading of Article 21 similarly changed over the years, and benches began to read the right to a 'healthy environment' into the right to life and livelihood, bringing the Court in line with an elite environmentalist lobby" (Vaidya 2016:8). An elite that cares about the quality of the air but also increasingly about the well-being of wildlife. This concurs with the words of Nayanika Mathur who explains that during the twentieth century "the first murmurings of conservationism began to be heard which posited the protection of wildlife as 'one of the marks of civilized conduct"' (Mathur 2016:8).

As for the suo moto PIL filed by Gauhati High Court, it is part of what is called "Judicial Activism" (cf. Baxi 1994; Dembowski 1999; Sivaramakrishnan 2011; etc.) which has also been on the rise since the 2000s. It is clear that the role of Gauhati High Court in the January 2013 judgment, just as that of the "Supreme Court of India in forest conservation, has been radically conservation-oriented, often to the detriment of forest dwellers (Kumar and Kerr 2012:755, quoting Rosencrantz and Lele 2008).

31 In a way the whole process fits in with what Anuj Bhuwania (in this issue) writes about trials concerning pollution issues in Delhi:

The Supreme Court acted supposedly on purely environmental grounds, marshalling the specter of vehicular pollution without adequately considering the impact its interventions would have on vulnerable sections of the population who live a hand-to-mouth existence, and without making any effort to cushion them from the harsh economic effects of such a transition. There was a callousness at 
work in which a blinkered and absolutist idea of environmentalism-Amita Baviskar called it "bourgeois environmentalism"-was imposed, where the poor are bizarrely and conveniently seen as responsible for urban pollution, and they have to bear the costs of moving to a more ecologically benign system (Bhuwania 2017).

Several authors have underlined this process (Baviskar 2003, 2010, among others); this is indeed the situation we are witnessing in KNP but with regard to wildlife protection.

Following the order by Gauhati High Court, KMSS convinced the villagers concerned to in turn file a writ petition at Gauhati High Court. Though somewhat passive when the decision to extend the Park was announced, villagers adopted a very radicalized attitude and brought this petition before the court in 2013: WP(C)4860/2013 (Gauhati High Court 2013). KMSS strongly supported them, and provided them with lawyers who are leading experts in the field of environmental protection, especially as some of them contributed to drafting FRA 2006. The lawsuits brought by farmers concerned by the Park's 2nd, 3rd and 5th additions clearly illustrate how legislation has evolved and how it is used or sidestepped.

In the writ petition, the complainants first recall that their lands are myadi patta (permanent land holdings) for which they have long paid touzy revenue (for the most recent in 1972, for others, in 1969, 1950 and prior to that) and they point out that, under the FRA, "all such temporary leases can be converted to permanent titles as per Section 3 (1) (g).“ (Gauhati High Court 2013:7).

One of their main arguments is that the very notion of "addition," used as evidence by the Forest Department and the Park administration, is invalid:

it is absolutely imperative to understand the scheme of law i.e. the WildLife (Protection) Act, 1972 (WLPA) vis-a-vis the declaration of Sanctuaries and National Parks, and the alteration of boundaries of such Sanctuaries and National Parks to appreciate the real and true import of the impugned Notifications which are masquerading as "Additions," the crucial point being that one actually will not find mention in either the WLPA or the Forest Rights Act of any concept of "Addition." One will find mention of boundary alteration, but Section 35 (5) of the WLPA clearly states that "No alteration of the boundaries of a National Park by the State Government shall be made except on a recommendation of the National Board." In this case, since no recommendation has been proffered, any alteration has been made with no legal grounds, and therefore is not valid in any sense. (Gauhati High Court 2013:8-9).

Here we can see the expertise of the lawyers who were involved in developing FRA 2006. ${ }^{15}$

The complainants refer to the definitions used, in particular the notion of what is forestland; a definition that has been the subject of ongoing debate in India. We will not dwell on this issue here; let us simply emphasize that there is no definition of the word "Forest" in the Indian Forest Act of 1927, nor in the Forest Conservation Act of 1980. Thus, the definition given by the Supreme Court of India in 1996 in the Godavarman case sets a legal precedent. ${ }^{16}$ And petitioners recall that:

Section 2(d) of the FRA defines Forest Land as "land of any description falling within any forest area and includes unclassified forests, un-demarcated forests, existing or deemed forests, protected forests, reserved forests, Sanctuaries and National Parks." Thus, ... "it is incumbent on the State Government to follow the due process under the law" ... "no claimant can be evicted in view of Section 4(5) of the Forest Rights Act" (Gauhati High Court 2013:23-24).

They also call to mind all the rights stipulated in the Forest Rights Act 2006, regretting that it was not properly implemented in Assam: 
it is ironical and shocking to note that neither the Sub-Divisional Level Committee nor the District Level Committee has been formed in this area to the best of our knowledge. Further, even the Forest Rights Committee, which is to be constituted under the Forest Rights Act and the Rules made there under Rule 3 has not been allowed to be created in the said area, which itself is a complete travesty of justice and denial of rights under a specific statute that is mandated to undo historic injustice (Gauhati High Court 2013:7-8).

The fact that these committees have not been created is hardly surprising since foresters, especially in Assam, are totally opposed to this Act. Alongside NGOs specialized in environmental protection and successive central governments, they have tried to limit its scope by introducing exceptions: in particular, the FRA's requirement-recognized by the Ministry of Environment and Forests in an order dated 30 July 2009-that no project receive forest clearance (to take forestland) without providing gram sabha (village assembly) certificates to prove that the FRA process is complete and that they consent to the takeover (see Campaign for Survival and Dignity N.d.) ${ }^{17}$ is one of the aspects of the law they are trying to circumvent. This is, for example, what the Prime Minister's Office attempted to do in 2012: to forgo gram sabha's agreement for "linear projects" (roads, power lines, etc.). The FRA has also thwarted the plans of Modi's government ${ }^{18}$ which, after having tried in vain to change the Land Acquisition Act, ${ }^{19}$ is trying to reclaim land for industrial purposes by bypassing it. Instead, FRA opponents wish to restore the rights of Joint Forest Management Committees (JFMC); though nominally "participatory," these committees are in fact controlled by local forest officials who hold all key posts in "participatory" bodies. However, the Supreme Court ruling of the Vedanta case in April 2013 has set a legal precedent in this field; reference is still made to it: "After the Supreme Court's Vedanta judgment the Tribal Ministry recently (March 7, 2014) pointed out to State governments that even this exemption is illegal and that gram sabha certificates are required in all cases" (Campaign for Survival and Dignity N.d.).

The FRA 2006 has ultimately made many opponents and there is no shortage of attempts to dispense with it. These attempts may come from environmental organizations such as the Nature Conservation Society, Tiger Research and Conservation Trust or the Wildlife Trust of India. The position they adopted at the Supreme Court in a Writ Petition 109/2008 (Wildlife First and Ors. vs. Union of India and Ors.) aims, among other things, "to set up an independent committee of experts to examine the implementation of the impugned Act ... and in particular the procedure adopted," "to direct the above mentioned committee ... to report as to the extent of forestland which has been physically occupied by ineligible claimants ... and the extent of forestland that has been recovered," "to direct the respondents to permit voluntary resettlement of people residing within national parks and sanctuaries without insisting on setting their rights under the Act" (Wildlife First and Ors. vs. Union of India and Ors.). ${ }^{20}$

Forest officials and hardline conservationists have filed a total of nine lawsuits in an attempt to get the Forest Rights Act or its associated orders abolished on the grounds that they are unconstitutional. They believe that by recognizing these rights, the FRA will encourage false claims and lead to the destruction of forests and above all, they do not recognize the authority of gram sabha. Kumar and Kerr recall that during the FRA's development phase, the Minister for Environment and Forests strongly opposed the proposed bill (Kumar and Kerr 2012:757). One of the reasons explaining this is that for the first time a forest-related law no longer falls under the aegis of the Ministry of 
Environment and Forests (MoEF) but under the Ministry of Tribal Affairs and therefore deprives foresters of certain powers.

Further into the text, petitioners who denounce foresters' behavior, refer to the right to life and livelihood inscribed in Article 21 of the Constitution of India, a right-it would seem-that courts do not put to the fore with regard to animal protection. To conclude, petitioners talk of

an illegal, undue and ex-facie, erroneous, unconstitutional, arbitrary, colorable exercise of power, not in accordance with either the Wildlife Protection Act, 1972, or the Forest Rights Act, and without application of mind, unjust, unfair, opposed to the principles of natural justice and, as such, they need to be revisited to ensure that due process is followed through appropriate writs including mandamus (Gauhati High Court 2013:24).

The implementation of the FRA, which was the result of a long struggle, was regarded as a victory by humanitarian organizations and by the lawyers who contributed to it. It was thought to represent "democratic progress" (Kumar and Kerr 2012:768). However, as we can see with KNP, it has been badly implemented, which is also the case in most Indian States (Government of India 2010; Kumar and Kerr, 2012:759, etc.). Moreover, although the FRA was introduced to try to resolve violent conflicts-it was considered part of a counterinsurgency strategy against Maoist groups (Vaidya 2016; Kumar and Kerr 2012:767) -, its non-implementation and its various readings have not solved problemsquite the contrary. The decision the High Court took on 9 January 2013 to evict people from these additions led, together with this writ petition, to a number of demonstrations that sometimes ended in violence.

\section{A political turn}

For several months these events prevented the evictions ruled by the High Court from taking place. But the May 2014 national elections which saw a $\mathrm{BJP}^{21}$ victory in India-and in a way in Assam ${ }^{22}$-appear to have accelerated the process. The man who led the PIL for the eviction of people from these additions, arguing that most of them were illegal Bangladeshi migrants, is Adviser to Hindu Yuva Chatra Parishad ${ }^{23}$ and former president of the Golaghat BJP unit. When I met him in November 2013, a few months before the elections, this "conservationist" who planted a tree every day, did not try to hide behind this PIL his prime objective to "get away" (sic) Bangladeshi migrants whom he considered illegal and a threat to the State of Assam-"Kaziranga is under encroachment of suspected Bangladeshi migrants"-but he complained that his PIL had had little impact. Since the elections he has regularly expressed his opinion in the press. The evictions he called for started in August 2014; for the time being they have only been carried out in part of the sixth addition (Saikia 2014). On 31 August 2014, The Assam Tribune wrote that a BJP leader "had moved the High Court against the suspected foreign nationals living in the sixth extended area of the Park" (The Assam Tribune 2014). In this case the "bourgeois environmentalism" that Amita Baviskar $(2003,2010)$ talks about in reference to PILs is tinged with xenophobia.

Faced with violent protests by people refusing to be evicted, Gauhati High Court asked for people to be relocated in model village ${ }^{24}$ but, in accordance with the previously quoted PIL, it also asked central and State governments to "verify the citizenship credentials of the encroachers in and around the UNESCO World Heritage Site before rehabilitating them" (The Sentinel 2014). However, despite the Court's injunctions, the local authorities 
who are familiar with the situation on the ground are having difficulty in evicting people from these additions, and even seem to no longer really want to. The Assam Government has acknowledged these encroachments but has not recognized encroachers as illegal migrants.

\section{... One more measure, one measure too many?} project which should lead to the eviction not only of farmers from the four additions already mentioned but also of shopkeepers, restaurateurs, hoteliers, etc. who have settled around the Park's perimeter. No doubt more violence has yet to come...

42

Zone in 2002. The aim was to define a buffer zone around protected areas where activities would be regulated. It was then decided to declare "lands falling within $10 \mathrm{~km}$ of the boundaries of National Parks and Sanctuaries" as eco-fragile zones under section 3(V) of the Environmental (Protection) Act, 1986, and Rule 5(viii) \& (x) of the Environmental (Protection) Rules, 1986. But faced with the challenge that several States were already engaged in numerous conflicts regarding their protected areas, it was decided in 2005 that "the delineation of Eco-Sensitive Zones would be site specific and related to regulation, rather than prohibition of specific activities" (Kaziranga Eco-Sensitive Zone 2015:11).

eless, Indian States were in no hurry to set up these ESZs. And this was the case of the State of Assam because, on the one hand, it already faced great difficulties in making additions to Kaziranga National Park, in evicting the inhabitants and in trying to settle the subsequent conflict and, on the other hand, because the growing number of hotels, dhaba, quarries, etc. around the Park are often the result of special favors and of corruption involving a large section of society, not to mention that they are also a means of survival for some of the population bordering the Park.

Given the States' limited reactions to this measure, in December 2006 the Supreme Court ordered all States and Union Territories to send to MoEF proposals regarding the demarcation of ESZs; failing this, a radius of 10 kilometers was to be applied around Protected Areas. But it was only on 5 November 2014 that a committee was set up by the Government of Assam. The Park authorities published an Approach Paper on KNP's ESZ on 6 April 2015, with notification of several scheduled Public Hearings. ${ }^{25}$ In the minutes of one of these Public Hearings, which was held on 18 June 2015 with members of KMSS, and as reported by the Director of the Park himself, one can sense the population's exasperation-these ESZs were the last straw. All the population's accusations regarding the conservation policy converge here. The public raised several demands and issues, and I will mention only a few:

5. The Kaziranga Tiger Reserve notification should be withdrawn. Instead of tiger project, rhino project only should be implemented in KNP.

6. There should be reservation of jobs for locals in the Forest Department recruitments for frontline staff.

11. Very little compensation is paid for the man-animal conflict victims and tiger kill, and that too after a long wait of several years. This situation should be remedied and actual market price should be paid instead of pittance.

17. Kaziranga is famous for rhino not for tiger. The Govt. should implement Project Rhino in Kaziranga.

18. Some NGOs are making money in the name of Project Tiger.

South Asia Multidisciplinary Academic Journal, 17 | 2018 
19. People should be allowed to do Chhat Puja on the Difaloo south bank ${ }^{26}$

31. On "Uruka" day, the "Garu Bihu" festival ${ }^{27}$ should be allowed on the left bank of Difaloo River.

32. The Mising and Karbi communities should be allowed to collect certain herbs from the forest areas for their annual religious festivals, etc. (Kaziranga EcoSensitive Zone 2015:13-14).

45

Public Hearing was accompanied on the very same day by large demonstrations: hundreds of protestors led by KMSS and ATTSA (Assam Tea Tribe Students' Association) blocked the National Highway (NH-37), demanding de-notification of an Eco-Sensitive Zone in Kaziranga and halting the ongoing eviction process in the additions to the Park. They even demanded the cancellation of work on these additions to KNP, and land pattas for indigenous people residing in the areas. Even the AASU (All Assam Student Union)which calls meetings in favor of the protection of rhinoceros and to drive out of Assam Bangladeshis whom they accuse of being encroachers and poachers (cf. Smadja 2013) joined the movement.

nite of this, Gauhati High Court has now turned against the State of Assam, its administration, its police and its local bodies demanding that they implement the eviction measures related to this ESZ as well as to Park additions (Gauhati High Court 2015).

The Supreme Court, like the High Court, has therefore embraced the environmentalist cause, relying on international laws, putting forward the UNESCO World Heritage label and tasking itself with prompting States to enforce conservation rules. Note once again how the authority of Courts of law prevails over the States' authority, as mentioned regarding lawsuits on pollution in Delhi by Bhuwania, among others in this volume, and which also led Sen to write:

The [supreme] court has become "embedded" in many aspects of governance, such as monitoring, overseeing and even directing government activity in matters of environmental policy, land planning, development, education, health care, etc. (Mate 2010:210). The court's role in adjudicating these claims [PIL] has resulted in the creation of a new corpus of constitutional rights and equitable remedies that have solidified the court's power and enabled it to assert limits on government authority (Sen 2015:39).

This new power is a great subject of debate in India since the law may then be an instrument used by groups in their own interest, thereby questioning the democratic and representative constitutional order (cf. Sen 2015:38).

\section{The intervention of the National Green Tribunal (NGT)}

The intervention of the NGT-federal judicial body whose specific mission is "the effective and expeditious disposal of cases relating to environmental protection and conservation of forest and other natural resources" (Amirante 2012:461)-has speeded up this process since August 2015. As underlined by Menon and Kohli (2016) quoting Dutta, "in more recent times the NGT has been regarded by environmental lawyers and activists as the 'epicenter' of the environmental movement in India."

The NGT relies on a PIL dating from 2012 which was brought before the court by a resident of Bokakhat, next to Kaziranga National Park, who for years used the Right To Information to obtain data on the Park situation. His main objective is to ban all illegal constructions around the Park, including the No Development Zone set up in 1996 around

South Asia Multidisciplinary Academic Journal, 17 | 2018 
Numaligarh refinery-which has barely been respected-as well as those within the EcoSensitive Zone.

Excerpts from the conclusion given by the National Green Tribunal clearly illustrate the situation (National Green Tribunal 2012):

The National Green Tribunal (NGT) on August 25, 2012, asked the Assam government to ensure that no construction whatsoever was permitted in and around the Kaziranga National Park, and directed it to submit a map of Kaziranga showing its boundaries and offending structures within five kms of the park boundaries.

The Applicant is a resident of village Bokakhat, and is concerned about the ecology of the area and future of the Indian Rhino, Elephant and wide species of flora and fauna available in the Kaziranga National Park. He has approached this Tribunal invoking jurisdiction under Section $14(1)^{28}$ of the National Green Tribunal Act, 2010, inter-alia, praying for appropriate directions to the Authorities to safeguard Kaziranga and its ecology. According to the Applicant, unregulated quarrying and mining activities permitted in and around the area of "Kaziranga National Park," not only threaten the Eco-Sensitive Zone, but also the survival and existence of Rhinos, Elephants and other wildlife species (National Green Tribunal 2012).

Here again we find the "new public" of PILs-environmentalist activists who above all defend nature-and the role of courts in the governance process: NGT went on to blame the central government and the State Government of Assam:

their callousness and apathy in protection of ecology of Kaziranga National Park which resulted in causing pollution thereby damaging the environment as well as ecology and Eco-Sensitive Zone. And it has directed the MoEF and the Government of Assam to deposit Rs. 100,000/- (Rupees one lakh only) each, with the Director, Kaziranga National Park for conservation and restoration of flora and fauna as well as biodiversity, Eco-Sensitive Zone, ecology and environment of the vicinity of Kaziranga National Park in general and within the No Development Zone in particular (National Green Tribunal 2012).

In July 2015, over 70 dhabas, restaurants, resorts, petrol pumps and other establishments were served notice of appearance before the NGT in connection with the same case, with the tribunal requiring them to state the rights they had over the land and whether the plots fall within the proposed Kaziranga National Park Eco-Sensitive Zone.

Given the street protests on the one hand and the boost NGT gave these cases on the other hand, the Assam Government has struggled to take a stance. For example, under the threat and the injunction dated 12 October 2015 to "clear" two KNP animal corridors, the State government referred to these two areas as "revenue villages" in a recent affidavit before the court, thereby contradicting its previous statement in which they were classified as reserve forest areas where people were not allowed to settle.

NGT appears to have increased the aforementioned power of upper courts in governing the country because NGT's "legitimacy" as an environmental protection body assisted by experts in ecology and its rapid response makes it a very powerful tool for judicial activism: "the environmental courts present several advantages: speed in judgments, efficiency, and trained specialized judges accustomed to dealing with non-judicial experts in the field." (Amirante 2012:448). But these experts focus on environmental protection, ecology, biodiversity; none of them come from the social sciences (cf. Amirante 2012; Menon and Kohli 2016), which in no way helps in improving the situation. 


\section{In the name of the fight against poaching}

53 surveillance cameras have been set up and since 2012 the Government of Assam has even been considering using drones to monitor the Park. An electronic monitoring system was installed in May 2015.

\section{regularly calls on the army to keep watch over it and the weapons the latter use have} been modernized to meet the degree of sophistication of the equipment used by poachers. Year after year, as the situation worsens, the Protection Force gets bigger. During the 2012-2015 period, the Assam government set up: the Assam Forest Protection Force; an anti-rhino poaching task force; a Rhino Protection Force; a centrally assisted special task force; and it recruited 300 staff members to run Kaziranga National Park in addition to 900 forestry officials. Inside the Park, there are over 150 anti-poaching camps. Some suggest dehorning rhinos to put an end to poaching (Tigernet 2014). And last but not least, in June 2016 "Dibrugarh MLA suggested that a ropeway system should be introduced in Kaziranga forest so that it would facilitate the Forest Guards to patrol the area at night." (Baruah 2016) 
fight is also being led on administrative and legislative grounds, and it is driven in particular by the Project Tiger administration. After the National Tiger Conservation Authority was created on 4 September $2006^{29}$ thanks to another amendment, the Wildlife Crime Control Bureau (Tiger and Other Endangered Species Crime Control Bureau) was set up on 6 June $2007^{30}$ "to strengthen the intelligence gathering and enforcement of law for control of poaching and illegal trade in wildlife and its products" (Tigernet 2013a). There is also a plan to reform the Wildlife (Protection) Act 1972, and that is why "The Wildlife (Protection) Amendment Bill 2013 has been introduced in the Rajya Sabha on 5 August 2013" (Tigernet 2013b). As part of this amendment, the term of punishment and the fines for committing offences under the Act are to be increased. It has not yet been passed.

a number of measures have been taken at national level, Assam has applied exceptional provisions in several fields. Indeed, the (Assam Amendment) Act, 2009, increased the sentence for poaching to life imprisonment (with a minimum of seven years) and a fine of no less than INR 75,000. Assam was the first State in the country to take this legal step. In 2013 the CBI (Central Bureau of Investigation) was empowered under the WLPA 1972 to apprehend and prosecute wildlife offenders, and an AntiCorruption Cell-II (AC-II) was tasked with seven cases of rhino killings in Kaziranga. Since April 2013 the CBI can call upon Interpol to investigate the international and inter-state connections of poachers who have killed rhinos in Assam. (The Asian Age, 2013). And in August 2015, of the seven cases mentioned above, three were transferred to the CBI's Special Crime Branch in Kolkata.

However, it is above all the law that was passed in July 2010 that grants even greater power to foresters in Assam; this is a way for them to defend their prerogatives after the Forest Rights Act was passed in 2006. Indeed, in July 2010 the Government of Assam passed a law under the provisions of Section 197 (2) of the CrPC (Criminal Procedure Code) according to which all forest officers and staff, including members of the Assam Forest Protection Force, are vested with the authority to use fire arms to protect forests and wildlife and they have been granted immunity from prosecution with no Government sanction. And in 2014 forestry staff running the State wildlife sanctuaries were provided with self-loading rifles to replace their old 303 rifles.

What must be stressed here is that foresters in India have always wielded considerable power, as Landy et al. remind us:

In India, as in many developing countries, the very extractive colonial vision of forest conservation has been supplanted by one of the most radical ecologies of North American inspiration. Yet the forest administration has managed to maintain the same practices while changing its philosophy: the supremacy of the fence, isolation and division still prevails. Far from pushing for more democratic methods, this succession of ethics, though different but both based on the nature/society opposition, has merely succeeded in strengthening the practice of top-down regulation which only takes people themselves into account when it is a question of evicting them or of prohibiting their rights (Landy et al. 2014:243). ${ }^{31}$

The power vested in wildlife wardens and in foresters by the Wildlife (Protection) Act 1972 and other Forest Acts, noticeably in Assam, where it was reinforced by the Assam Forest Protection Act of 1986, has increased over the years. This Act provides for the creation of the Assam Forest Protection Force whose supervisory officers have been equated with police officers. Wide-ranging powers are vested in them under the Criminal Procedure Code. This means that any issue relating to damage by wildlife, evictions, 
poaching, whether within protected areas or in the surrounding area, are under the aegis of the Forest Department. Forestry staff have the right to shoot people on sight if they enter the Park, to arrest people, to take them in for questioning and to take down their statements, etc. The 2010 amendment includes an additional step and has fuelled a latent conflict between the Forest Department and police. As the State Minister for Forests put it in October 2010 following the President of India's approval of the amendments to the Wildlife (Protection) Act which are only applicable to Assam: "uniformed forest guards would also enjoy an open hand as steps have been taken to ensure that they are not subjected to unwanted hassle from the police department" (The Assam Tribune 2010). This decision illustrates the confrontational relationships between foresters and the police.

In fact, Kaziranga's forest officials complained to Gauhati High Court that the State police were not giving enough priority to cases of wildlife crimes, such as rhino poaching, and that the poachers arrested were never convicted (Thakur 2015b). Just as in civil cases, which are handled promptly by the National Green Tribunal, KNP authorities would like swift justice for poaching. A conservationist from Aaranyak (an ONG working on wildlife protection in KNP's surrounding area) considers that "there is delay in filing complaint under the Wildlife Protection Act and evidence gathering is very slow. Cases hang on for 10-15 years. Cases involving Scheduled species such as rhino, tiger, elephant, etc., should, in fact, be tried in fast-track courts," adding that "rather than waiting for the police, the Forest Department should register cases directly at the Chief Judicial Magistrate's court under the Wildlife Protection Act" (Thakur 2015). These are additional powers that the Department of Forest would be granted at the police's expense. All these requests have been made within the framework of "Project Tiger," a project that has strengthened the laws relating to the protection of nature and the power of forest authorities. Some do not hesitate to say that "Tiger reserves are administrated in a remarkable fashion as mini police states" (Campaign for Survival and Dignity 2012).

In the field, the situation observed up until November 2013 seems to be rather inextricable. The poachers I met had killed rhinos; they had been arrested and sent to jail, then released on bail. Their case at Golaghat District Court is pending. Confronted with the Forest Department and the Court, they seem to be at a total loss: while the Forest Department's report is in English, their confession is written in Assamese, and many of them do not even know how to read or write and do not know what they are signing. In court, discussions are held in English, with the accused not understanding anything most of the time. But it is mainly in relation to the money they have to pay that we can see the extent to which the situation is without solution. In order to secure bail, poachers have to pay INR 50,000. This money can of course only come from poaching. Moreover, cases are left pending for years. And while a case is still pending, poachers have to appear before the Court every fortnight. On each of these occasions they have to pay their travelling expenses, their lawyer's fees and the Court, all of which amounts to INR 500, that is INR 1,000 a month. This is a considerable amount of money for them. In the end, the poachers I met surrendered because they were encouraged to do so by the journalist-cum-"social worker" I have already mentioned and by a wildlife-protection NGO that gave them hope of being rehabilitated. All this was done during an official ceremony attended by journalists, the Forest Department and Kaziranga National Park staff, officials, etc. The Forest Department promised to issue them with a paper proving that they had surrendered and to help them find a way of earning a living. They have not received anything since then. To obtain a final judgment and for the case to be dismissed, the 
lawyer asks them for another INR 50,000 which a farmer simply does not have. It is obvious therefore that they will go back to poaching and all the more so because, since they turned themselves in, they have been threatened by smugglers and active poachers who accuse them of being informants for the Forest Department.

So far all the measures taken to stop poaching have remained ineffective; it is on the rise. Whereas an average of ten rhinos was killed every year from 2001 to 2011, since 2011 more than twenty-five rhinos have been killed every year. And up until 2013 about five to ten poachers were killed each year and twenty or so were arrested, whereas in 2014 twenty poachers were killed and more than forty arrested around KNP alone.

This situation is not specific to KNP or even India but, as reported by Ansie Venter, the prosecutor in cases of poaching rhinoceros in Kruger Park, South Africa, where more than 1,215 rhinoceroses were killed in 2015: "no matter how much we despise and hate the people we catch, we must not forget that they are uneducated people who are desperate for revenue" (LeMonde.fr 2015). ${ }^{32}$ Whether in South Africa or in Assam, smugglers go unpunished.

And the measures taken so far among the populations are not likely to do anything to slow down this process. The measures cited by the Ministry of Environment and Forests include: awareness and education programs among the various communities; community participation through Eco-development Committees; community-based wildlife Ecotourism. But the "Ethnic-villages" where there has been an attempt to develop ecotourism are now in a moribund state because they have not at all met people's expectations: people say that they had to build traditional houses on stilts although they would have preferred to have modern ones made out of concrete; children had to learn long-forgotten songs and dances they had to perform every day in front of tourists, sometimes at the expense of their own schooling; and the revenue from tourism was insufficient. These kinds of issues are also highlighted by Benabou (2012b), among others, with regard to Eco-development in the Nanda Devi area. The poachers I met are also often involved in eco-tourism activities.

\section{The tiger and the rhinoceros, flagship species, banners of a fight}

To better understand the situation and the measures taken, whether administrative or legislative, one also has to consider the underlying positions of each and every party involved. Indeed, the fight against poaching, which is used to justify any measures taken to fulfil this cause, is a struggle laden with symbols that are widely used by various stakeholders for purposes that do not always have anything to do with nature protection.

Three decades after it became a National Park, Kaziranga became synonymous with Assam and with the one-horned rhino, the State's most recognizable symbol. It has become the official logo for The Assam Regiment and for many companies and corporations, such as travel agencies, bus companies, etc. (cf. Gokhale and Kashyap 2005:30). It has also become a symbol for Hindu nationalists who associate it with Assam and with, so they say, "the purity of their land which would be invaded by Bangladeshi Muslims."

During the May 2014 election campaign ${ }^{33}$ in Assam, rhinos featured in political party manifestos. Kaziranga's one-horned rhinos became a political issue, with the opposition blaming Congress for the rise in poaching in the National Park. In a paper called "In 
Assam, Kaziranga's Rhinos Become Election Plank", Samudra Gupta Kashyap, quoting the candidates' words, writes:

“The Congress has not only failed to protect Assam's indigenous communities from the invasion of Bangladeshi infiltrators, but has also failed to protect Kaziranga's one horned rhinos" said Arun Kumar Sarma, Asom Gana Parishad's (AGP) ${ }^{34}$ candidate for the constituency. (Kashyap 2014).

The man who filed the main PIL leading to the eviction of populations from KNP additions and to numerous measures against poaching, said: "It is not just that rhinos have been killed. A portion of Kaziranga is under encroachment of suspected Bangladeshi migrants." (Kashyap 2014)

71 And at the outcome of these elections, Narendra Modi, the Indian Prime Minister, said during an election rally in Dhemaji, in Assam:

Aren't rhinos the pride of Assam? These days there is a conspiracy to kill it. I am making the allegation very seriously. People sitting in the government... they are doing this conspiracy to kill rhinos so that the area becomes empty and Bangladeshis can be settled there (Press Trust of India 2014).

And he also warned that the poaching of rhinos would not be tolerated:

Those who are conspiring to gnash off rhinos, they should listen to this carefully. After May 16, they will be taken to task one by one (chun chunk e hisab liya jayega). ... We have to save the future of Assam. It is our responsibility to save it from forces which are looting the state (Press Trust of India 2014)

The then State Minister for Forests, a Muslim, was also accused of being behind poaching activities. (Saikia 2014). He was replaced in 2015.

As shown in previous work (Smadja 2013), Hindu nationalists place the purity of the National Park, which is dedicated solely to nature, on a par with Assam's and they regard the rhino that is said to be threatened by Bangladeshi migrants as a symbol of it. In actual fact, they defend the boundary of the National Park just as they defend the border between India and Bangladesh. This is a similar process to the one underlined by Omar Khalidi who shows how the Archaeological Survey of India and some tourism policies are in a way handmaidens of Hindutva, by describing India's past as the "Hindu golden age" and all subsequent periods until the colonial era as the age of Muslim vandalism (Khalidi 2010). This mixture of styles echoes the study conducted by Emma Mawdsley (2010) about the case of Tehri Dam and of the World Hindu Council, a militant nationalist organization, whose rhetoric-which is used to protest against the dam's construction-is linked to anti-Muslim action. This association between "the Green and the Saffron" (see Sharma 2001, 2002) is not uncommon regarding environmental issues in India. In his book Green and Saffron: Hindu Nationalism and Indian Environmental Politics, Sharma (2011) explains how Hindutva activists have embraced environmentalism to articulate their socio-political goals. As shown in the book edited by Guneratne (2010), in India ecological degradation has become a metaphor for cultural degradation (Rademacher 2010; Mawdsley 2010). 
Photo 3

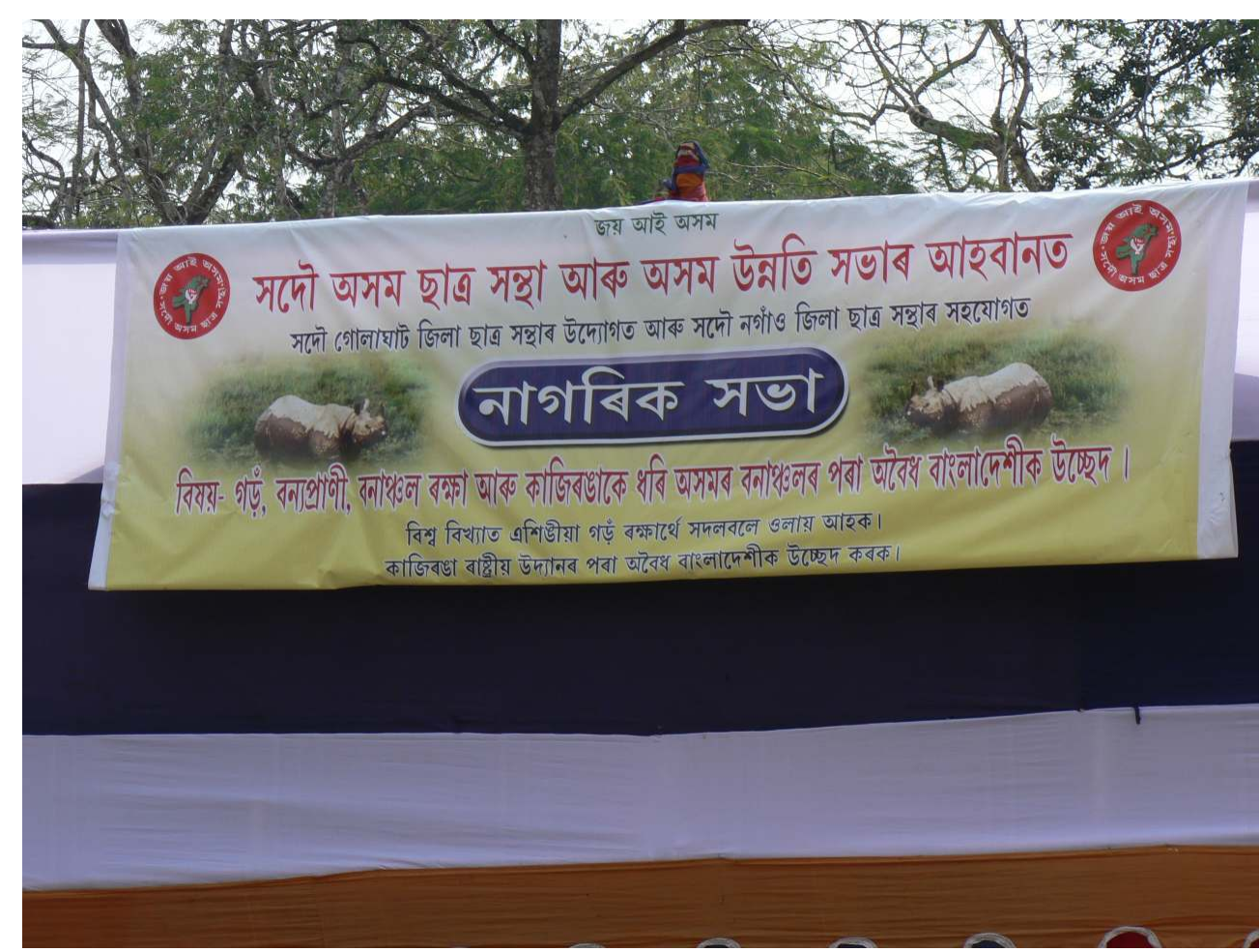

POSTER OF A MEETINg CALLED BY AASU (ALL ASSAM STUDENT UNION) IN MAY 2008 NEAR KAZIRANgA NATIONAL PARK. SUBJECTS GIVEN ON THE POSTER: RHINO / WILDLIFE / PROTECTION OF HABITAT, FOREST / FROM FOREST REMOVE ILLEGAL BANGLADESHI ENCROACHERS.

PHOTO J. SMADJA, MAY 2008

The protection of the rhinoceros has ultimately won unanimous support, even among farmers who suffer the depredations of wild animals and are subject to eviction from the additions to the Park. It may seem surprising that their complaints do not concern the rhinoceros or the elephant but only the tiger and Project Tiger; and that Project Tiger is only supported by the Park and the Forest Department, not by local nature protection activists. Among the reasons that farmers give for this is that a tiger, a carnivore, kills and frightens people; it can be a man-eater, and it kills cattle, which are essential if a farmer is to work his land and survive. Moreover, a tiger is a cunning animal: you don't hear or see it come. While the rhino, and the elephant (which in addition is sacred), are herbivores. You can hear them, you can try to chase them away and they can possibly be contained behind electric fences, which is not the case of tigers. Last but not least, to protect tigers, more land is being confiscated from farmers as part of Project Tiger. Finally, it appears that the transformation of Kaziranga National Park into Kaziranga Tiger Reserve came with profound changes that have aggravated the situation. The populations bordering the park vehemently condemn this project with its extensive administrative and legislative powers, a project which aims at expanding the undisturbed areas for tiger by reducing human pressure-a condemnation in which the symbolic aspect also plays an important role. In actual fact, the tiger, which is the current popular mark of global conservation, is the national animal both of Bangladesh and India. Many people in Assam make the link between tigers, Bangladeshi migrants and the central government which was said to do nothing to evict the latter. This partly explains the attitude of many farmers I interviewed around Kaziranga National Park, who see the tiger 
as a "foreigner" that the central government, ${ }^{35}$ supported by international environmental legislation, reintroduced into the Park, threatening rhinos and the populations. As Amita Baviskar and Annu Jalais explain, this type of belief needs to be taken into account because this metaphor tries to make sense of the imported concept of conservation which seems to be "consuming and alienating local resources" (Jalais 2010:172, quoting Baviskar). Samuel Depraz also reminds us that "in many cases, managers of protected areas will find themselves the target of criticism, not so much because they are the underlying reason for the motive, but because they embody both the exogenous authority on the territory, scientific expertise and an exogenous social group" (Depraz 2008:286). ${ }^{36}$

Photo 4

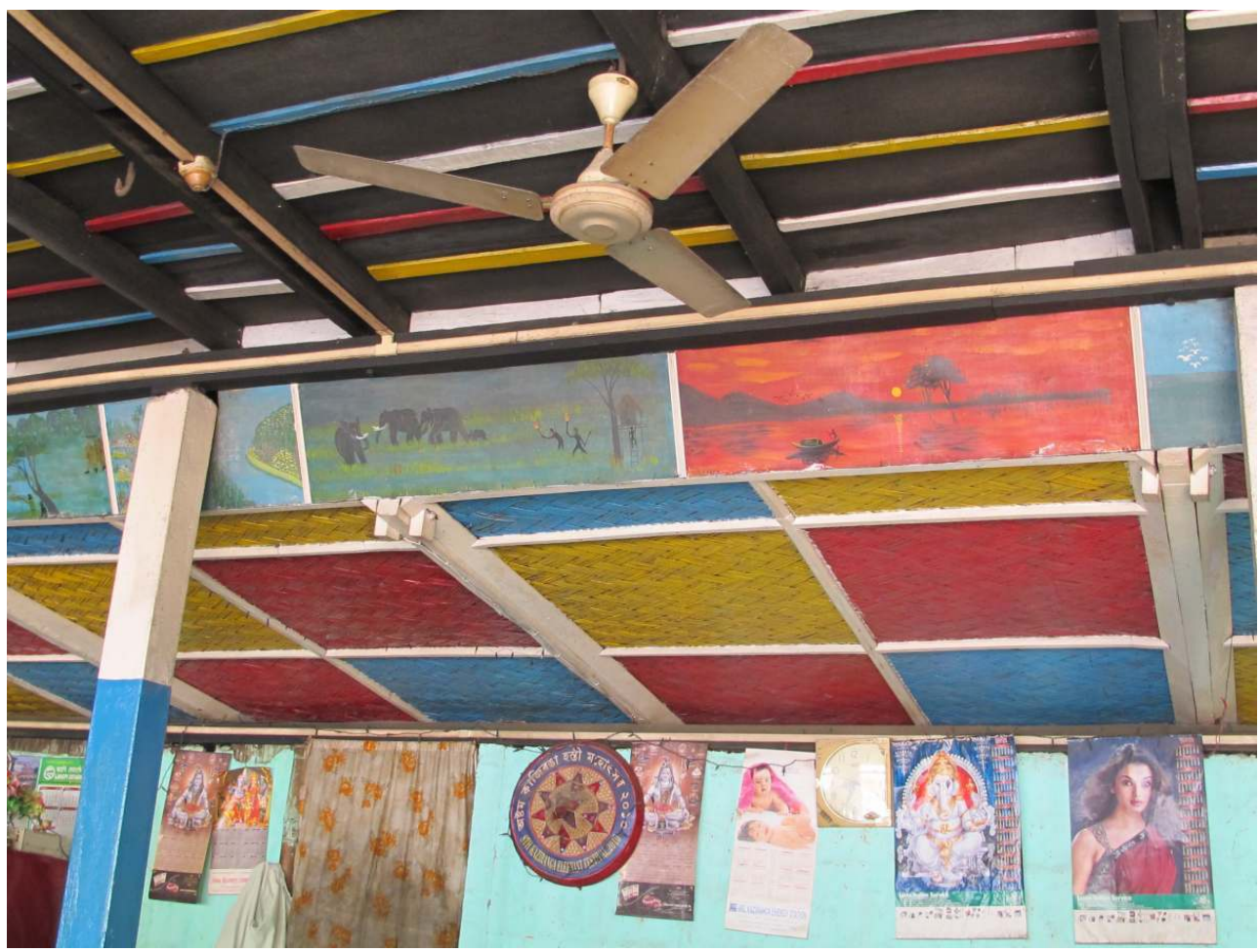

PAINTINgS DONE ON THE WALLS OF A SMALL RESTAURANT NEAR THE PARK CLEARLY ILLUSTRATE THE SITUATION THERE AND THE WAY ANIMALS ARE PERCEIVED BY THE POPULATION.

PHOTO J. SMADJA, OCTOBER 2013 


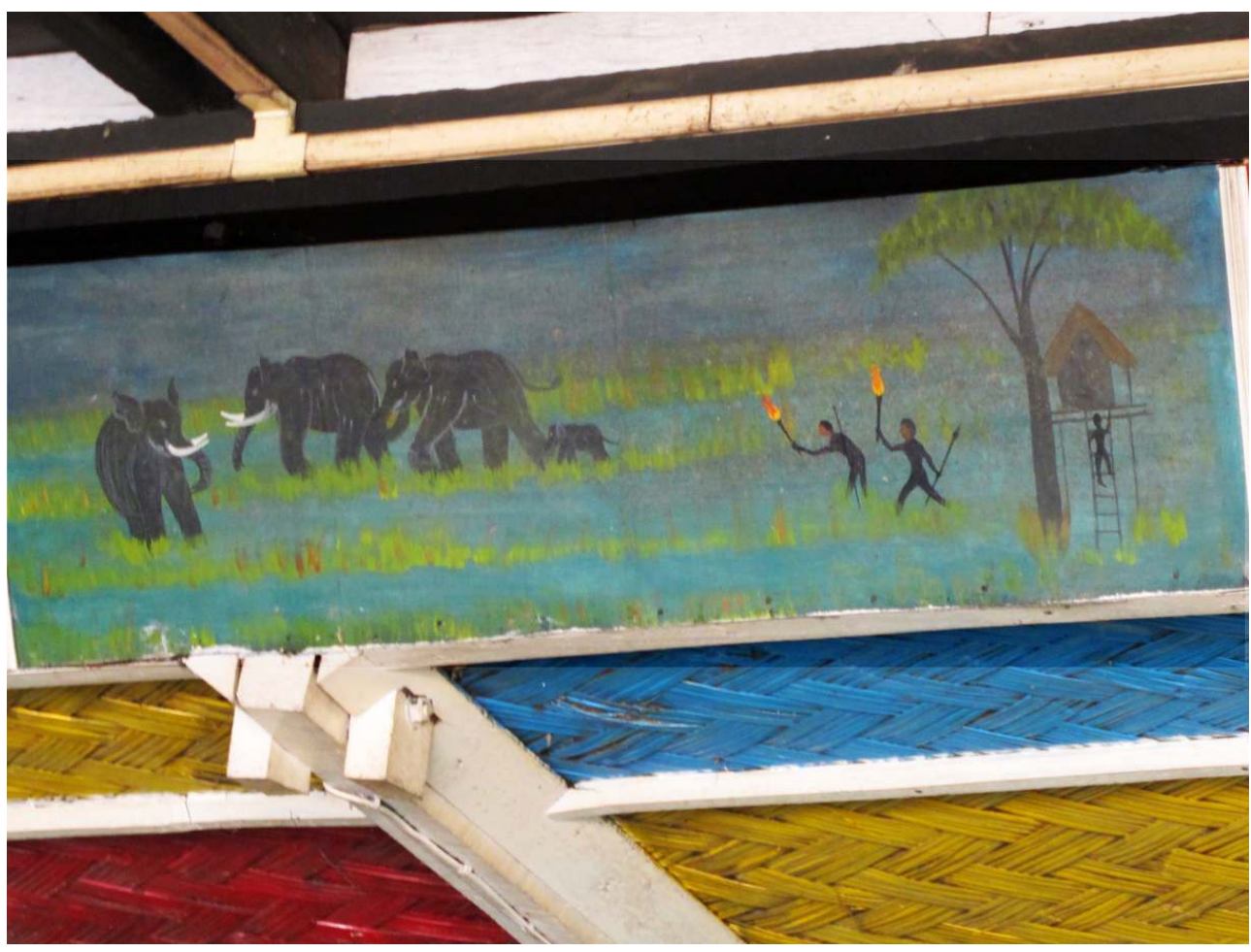

THE ONLY THINg PEOPLE ARE ALLOWED TO DO TO CHASE AWAY WILD ANIMALS IS TO SHOUT AND LIgHT TORCHES WHEN KEEPING WATCH FOR THEM AT NIgHT.

PHOTO J. SMADJA, OCTOBER 2013 


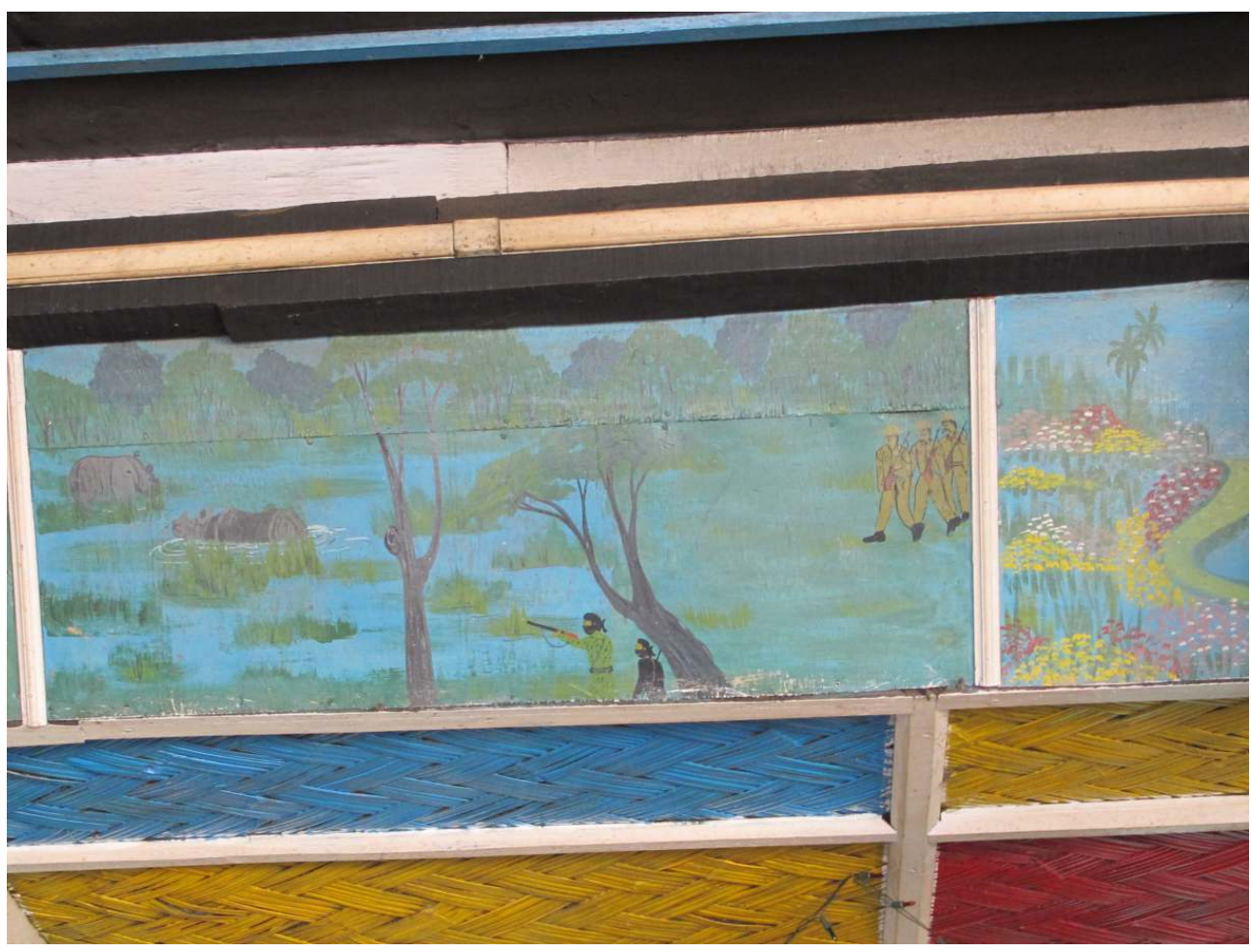

REPRESENTATION OF THE POACHING OF RHINOS REFERRINg TO THE AUTONOMIST MOVEMENTS AND THE INSURRECTION THAT TOOK PLACE IN ASSAM.

PHOTO J. SMADJA, OCTOBER 2013 


\section{Photo 4c}

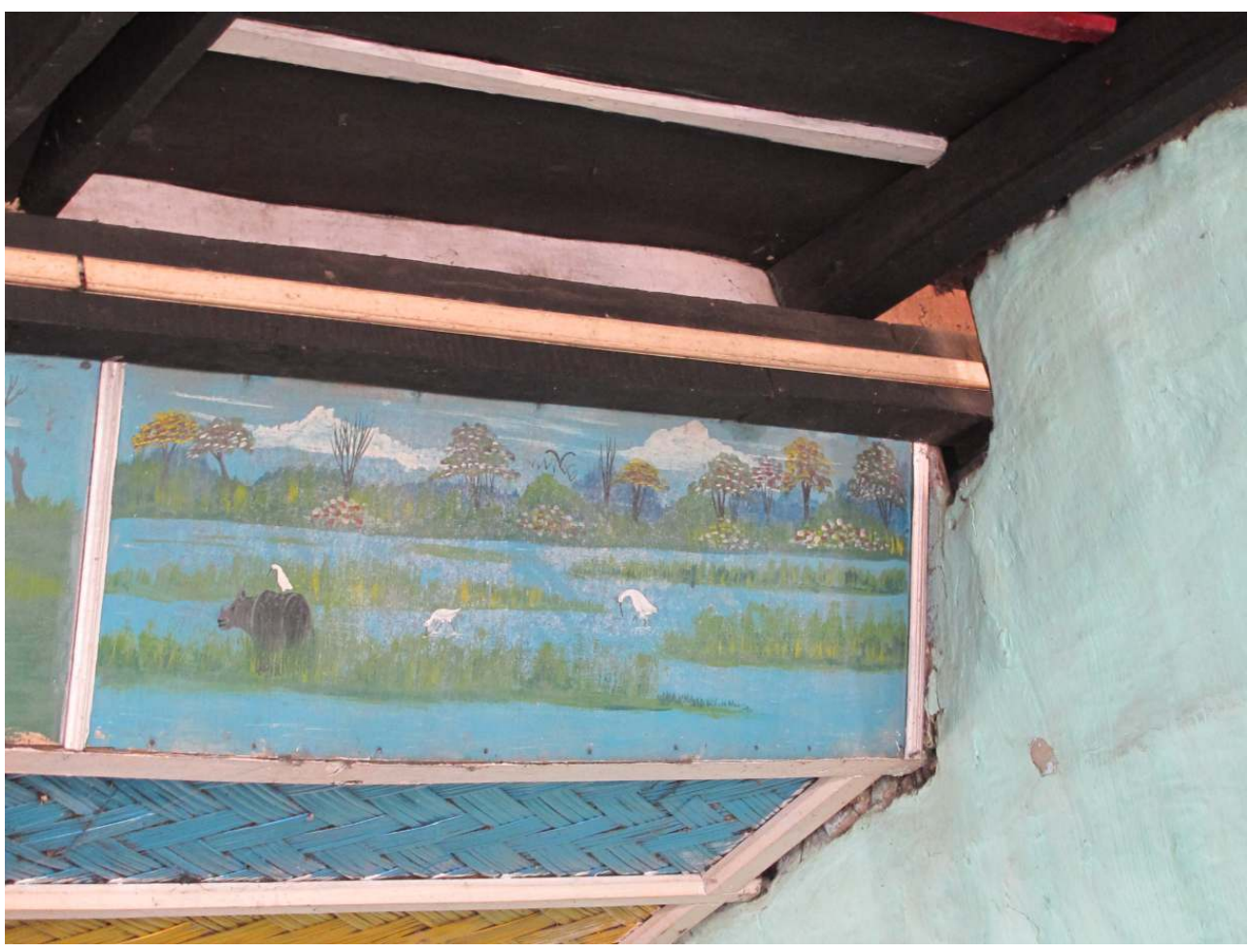

THE RHINO IS REPRESENTED AS A PEACEFUL ANIMAL-THE SYMBOL OF ASSAM-IN A BEAUTIFUL LANDSCAPE, AN EDEN, WITH THE HIMALAYAS IN THE BACKgROUND, LUXURIOUS TREES, AN EgRET ON ITS BACK.

PHOTO J. SMADJA, OCTOBER 2013 


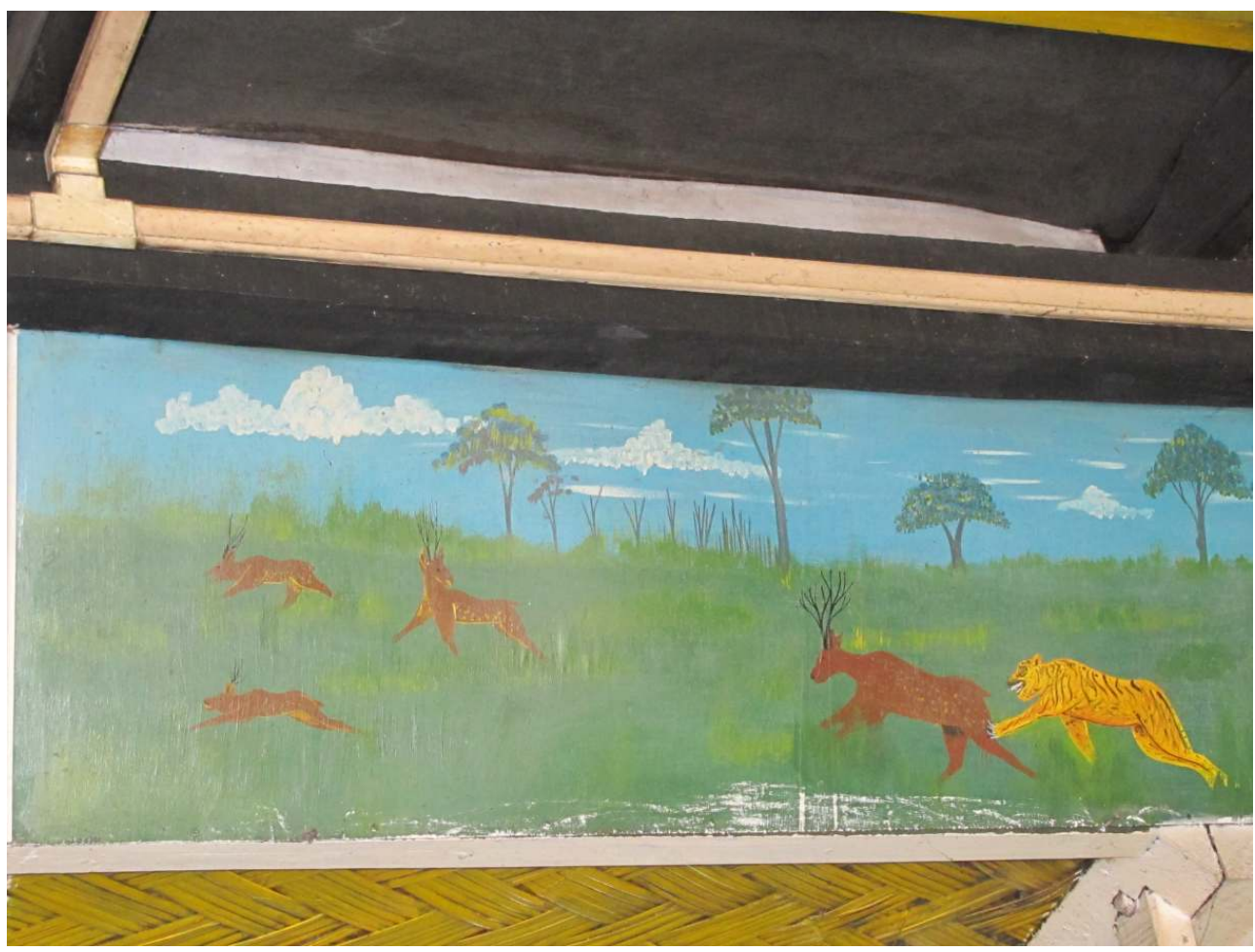

UNLIKE THE RHINO, THE TIgER IS REPRESENTED AS A KILLER, KILLINg EVEN PROTECTED WILDLIFE INSIDE THE PARK.

Photo J. Smadja, October 2013

Just as Annu Jalais demonstrated with regards to the tiger in the Sunderbans, some representations of wild animals are ultimately linked to power (Jalais 2010:9), and the Kaziranga study draws special attention to this. This is also exemplified by what Ananda Banerjee reports: at a meeting of the National Board for Wildlife in March 2015, Modi's government suggested that the Asiatic lion replace the tiger as India's national animal. Indeed, prior to 1972, the lion was India's national animal. The Indira-Gandhi-led Congress government replaced it with the tiger when it launched Project Tiger-the country's first wildlife conservation program. The Indian lion (or the Asiatic lion) is only found in Gir National Park and its surrounding area in Gujarat which, incidentally, happens to be the Prime Minister's home State. (Banerjee 2015).

As for the Forest Department, it needs Project Tiger because of the very substantial funding it provides, but also because the draconian laws governing this project allow it to firmly establish its power.

Therefore, though efforts may be called for and eventually agreed upon to protect the rhinoceros or the elephant, the protection of the tiger nevertheless provokes a feeling of rejection because this animal evokes values that are not shared: the tiger and the rhinoceros are not only a natural heritage but also a cultural one. These symbols are not taken into consideration by courts of law or currently by the National Green Tribunal which mainly relies on scientific expertise to assert the legitimacy of its decisions. 


\section{Conclusion}

78 Encounters between wildlife and farmers have always taken place in the area around Kaziranga, and the setting up of the National Park created problems from its very inception-an altogether banal situation of territory sharing that can be found throughout the world (Guyot 2006, Rodary 2008, etc.). However, in India and particularly in Kaziranga, an accumulation of nature conservation measures, increasingly coercive legislation and political demands that have grafted themselves onto fights over nature protection have led to an explosive situation that has ended neither in a better protection of nature-poaching is on the rise-, nor in a better protection of the population.

The situation around Kaziranga National Park raises many issues. It shows the complexity of protecting nature, especially wildlife, in densely populated areas where people live off their environment, not just in their environment (Landy 2010 in Landy 2014:229), which is often the case for elites.

The Park's nature-conservation policy which totally excludes populations from its perimeter and from its management has led to a dispute about legitimacy:

Whether it be about the actors or the practices, the question of legitimacy refers to an essential mechanism in any heritage process, namely the appropriation of the resource: who perceives its heritage dimension? Who shares this view? Who is victim of this, that is to say, dispossessed of their former relationship with this resource because of this heritage innovation? Conflict resolution in this case implies arbitration between the various legitimacies that oppose each other, in increasingly interwoven configurations. As a matter of fact, the legitimacy quarrel unfolds into multiple dimensions: territory, identity, practices, representations and, of course, the perception of the heritage resource ${ }^{37}$ (Gauchon 2014:101).

In Kaziranga, what or who is to be protected: endangered wildlife or the populations whose survival is threatened by this wildlife? How are both to be protected? Laws and measures exist to protect both of them. However, the Kaziranga example provides an overview of the problems major laws or measures have created in the field of environmental protection in India, whether it is a question of them being applied too rigidly, of them being bent or of them not being applied at all. The implementation of WPA in 1972 to protect wildlife, which was indeed in danger, largely tipped the balance in favor of protecting wildlife at the expense of the right to life and livelihood of the people, inscribed in Article 21 of the Constitution of India. The PILs that were originally introduced to defend this right to life and livelihood of disadvantaged groups have been bent for the benefit of environmentalists' concerns about the quality of their environment and of their lifestyle. Moreover, the way nature protection is used for political purposes in these PILs concerning Kaziranga adds to the criticism of these procedures which were supposed to be democratic tools. As for FRA 2006-the only law explicitly developed to "undo [the] historic injustice" that the poorest people suffer-it is simply not applied in Assam. On the contrary, those working on nature protection are backed by powerful administrative bodies such as Project Tiger, by a forestry body with extensive powers defending its own prerogatives, and are spurred on by international labels such as UNESCO's “World Heritage." Yet, despite their willingness to protect both wildlife and people, international organizations are not entirely neutral since we can read for example on the UNESCO and IUCN website: "In the heart of Assam, this park is one of the last areas in eastern India undisturbed by a human presence" (UNESCO N.d.). The 
2008 IUCN report reads: "the committee notes the important on-going efforts of the State Party to protect the property, in particular for the strategic extensions to the National Park in order to address issues of integrity affecting the existing property" (UNESCO 2008). And, the 2011 report: "The reports received by IUCN note that a government notification of 14 July 2010 provides all forest officers in Assam immunity from prosecution without prior sanction for use of firearms in carrying out their duty of forest and wildlife protection, which is a significant step to prevent poaching and boost staff moral" (UNESCO 2011). We have reviewed the issues that have stemmed from these decisions. Nevertheless, courts that have taken up the environmental protection cause rely heavily on these international labels and base their legitimacy on scientific expertise, leaving aside cultural and social aspects, which is especially the case with NGT. Through their judgments we can see the power they exert over States and their role in the governance of the latter, which has led some to say that these Courts rule India: "the courts participate and collaborate in governing India." (Mehta 2006:162 quoted by Sivaramakrishnan 2011:905). All of this fuels conflicts. And villagers are now supported by political movements calling for protests that can end in violence.

81 As Agnès Michelot who works in Africa puts it: "The legal dimension which is supposed to support a sustainable resource management strategy can in some cases even be a source of conflict or even be a factor itself in the environmental crisis." ${ }^{38}$ (Michelot 2006:119)

To conclude, concerning this complex situation, let me borrow Dembowski's words:

environmental challenges are always among the most difficult any polity faces. This is the reason why they are good test cases to investigate questions of governance in general. Environmental matters affect economy, culture, social habits and security, traditions and the distribution of incomes. Even in countries much richer than India (Germany for instance), the policy arenas are haunted by fancy rhetoric followed up by merely symbolical, ineffective measures. However, the gap between what is official legislation and what occurs on the ground floor level seems to be particularly wide in India (Dembowski 1999:55).

\section{BIBLIOGRAPHY}

Amirante, Domenico. 2012. "Environmental Courts in Comparative Perspective: Preliminary Reflections on the National Green Tribunal of India." Pace Environmental Law Revue 29(2):441-69. Retrieved May 10, 2015 (http://digitalcommons.pace.edu/pelr/vol29/iss2/3).

Banerjee, Ananda. 2015. “Does Narendra Modi like lions more than tigers?” Mint, Mumbai, 25 April. Retrieved October 16, 2015 (http://www.tigernet.nic.in/Alluser/GA_Detail.aspx?GA_Id=332 ).

Baruah, Debashish. 2016. "Govt. Charts Plans to Stop Rhino Poaching." The Assam Tribune, Guwahati, 8 June. Retrieved June 25, 2016 (http://www.assamtribune.com/scripts/ detailsnew.asp?id=jun0816/at052).

Baviskar, Amita. 2003. "Between Violence and Desire: Space, Power, and Identity in the Making of Metropolitan Delhi.” International Social Science Journal 55:89-98. 
Baviskar, Amita. 2010. “Indian Environmental Politics: An Interview.” Transforming Cultures eJournal 5(1). Retrieved May 10, 2015 (http://epress.lib.uts.edu.au/journals/TfC).

Baxi, Upendra. 1994. Inhuman Wrongs and Human Rights: Unconventional Essays. New Delhi: HarAnand Publications.

Beck, Corinne. 2006. "Ressources naturelles, partage social, conflits: Introduction." Pp. 17-20 in Temps et espaces des crises de l'environnement, edited by C. Beck, Y. Luginbühl and T. Muxart. Paris: Éditions Quae.

Beck, Corinne, Yves Luginbühl and Tatiana Muxart, eds. 2006. Temps et espaces des crises de l'environnement. Paris: Éditions Quae.

Benabou, Sarah. 2012a. “Conserver la nature par l'exclusion des hommes? La lutte pour l'accès et l'usage des ressources dans la réserve de biosphère de Nanda Devi, Uttarakhand (Inde)." PhD dissertation, Paris, EHESS.

Benabou, Sarah. 2012b. "Transforming Rural Livelihood through Eco-Development in the Nanda Devi Biosphere Reserve." Pp. 36-53 in Nature, Environment and Society: Conservation, Governance and Transformation in India, edited by N. Lainé and T.B. Subba. New Delhi: Orient Black Swan.

Berti, Daniela. 2015. “Gods' Rights vs. Hydroelectric Projects. Environmental Conflicts and the Judicialization of Nature in India: The Human Person and Nature in Classical and Modern India." Alla Rivista Degli Studi Orientali, Supplemento No. 2, Nuova Serie, LXXXVIII, Sapienza, Università di Roma, Dipartimento di Studi Orientali:111-30.

Berti, Daniela and Gilles Tarabout. 2015. "Practices of Justice: Categories, Procedures and Strategies." DIOGENE 60(3-4):3-11.

Bhuwania, Anuj. 2017. "The Case that Felled a City: Examining the Politics of Indian Public Interest Litigation through One Case.” SAMAJ 16 (https://samaj.revues.org/4413).

Bora, Pranab J., Amit Sharma, Ramesh Bhatta, Garga Mohan Das, S.N. Buragohain and D.D. Gogoi. 2009. Human and Tiger Interface in Kaziranga Tiger Reserve: A Technical Report. WWF and Department of Environment and Forests, Government of Assam.

Campaign for Survival and Dignity. N.d. "The Forest Rights Act. A weapon of democracy in the forests". Retrieved October 16, 2015 (https://forestrightsact.com/). Website partially retransferred to: http://www.indiaenvironmentportal.org.in/category/40763/publisher/ campaign-for-survival-and-dignity/.

Campaign for Survival and Dignity. 2012. "Tiger Reserves: The Realities Behind a Controversy," 31 August. Retrieved October 16, 2015 (http://www.countercurrents.org).

Comaille, Jacques, Laurence Dumoulin and Cécile Robert. 2010. La Juridicisation du Politique. Paris: Droit et Société, LGDJ.

Crémin, Emilie. 2014. “Entre mobilité et sédentarité: les Mising, 'peuple du fleuve,' face à l'endiguement du Brahmapoutre." PhD dissertation, Université Paris 8 Vincennes Saint-Denis.

Dembowski, Hans. 1999. "Courts, Civil Society and Public Sphere: Environmental Litigation in Calcutta." Economic and Political Weekly 34 (1/2):49-56 Retrieved May 10, 2015 (http:// www.jstor.org/stable/4407549).10, 2015

Depraz, Samuel. 2008. Géographie des espaces naturels protégés: genèse, principe et enjeux territoriaux. Paris: Armand Colin. 
Di Fonzo, Martina I. 2007. "Determining Correlates of Human-Elephant Conflict Reports within Fringe Villages of Kaziranga National Park, Assam.” Master's thesis, University of London and Imperial College.

Gauchon, Christophe. 2014. "Une composante des conflits environnementaux: la querelle de légitimité.” Pp. 86-102 in Les espaces protégés: Entre conflits et acceptation, edited by L. Laslaz, C. Gauchon, M. Duval and S. Hétitier. Paris: Belin.

Gauhati High Court. 2013. Writ Petition WP (C) 4860/2013, In re Sri Sunil Das \& Ors Petitioner v. State of Assam \& Ors

Gauhati High Court. 2015. PIL (suo motu) 66/2012, 67/2012, and WP(C)648/2013 and 4860/2013, In re Kaziranga National Park v. Union of India \& Ors. Retrieved May 20, 2016 (http:// ghconline.gov.in/Judgment/PIL662012.pdf).

Gauri, Varun. 2014. "Fundamental Rights and Public Interest Litigation in India." Pp. 79-108 in The Shifting Scales of Justice: The Supreme Court and Neo-liberal India, edited by M. Suresh and S. Narrain. New Delhi: Orient Black Swan.

Gokhale, Nitin A. and Samudra Gupta Kashyap. 2005. Kaziranga, the Rhino Century. Kaziranga Centenary Celebration, 1905-2005.

Government of India. 2010. "Report of the National Committee on Forest Rights." New Delhi, Ministry of Environment and Forests.

Guneratne, Arjun, ed. 2010. Culture and the Environment in the Himalaya. New Delhi: Routledge. Guyot, Sylvain. 2006. Rivages Zoulous. Paris: Karthala.

Jalais, Annu. 2010. Forest of Tigers: People, Politics \& Environment in the Sundarbans. New-Delhi: Routledge.

Kashyap, Samudra Gupta. 2014. “In Assam, Kaziranga's Rhinos Become Election Plank.” Indianexpress.com, 6 April. Retrieved May 5, 2015 (http://indianexpress.com/article/india/indiaothers/in-assam-kazirangas-rhinos-become-election-plank/).

Kaziranga Eco-Sensitive Zone. 2015. Draft Proposal. Government of Assam, Kaziranga National Park, 10 July.

Khalidi, Omar. 2010. "ASI is the handmaiden of Hindutva." In Rediff.com India News, 1 October. Retrieved October 15, 2015 (http://news.rediff.com/column/2010/oct/01/column-asi-is-thehandmaiden-of-hindutva-writes-omar-khalidi.htm).

Kumar, Kundan and John M. Kerr. 2012. “Democratic Assertions: The Making of India's Recognition of Forest Rights Act." Development and Change 43(3):751-71.

Landy, Frédéric, Emmanuel Bon and Marie-Hélène Zérah. 2014. "La forêt dans la ville? Conflits d'acteurs autour du Parc national Sanjay Gandhi de Mumbai (Bombay, Inde)." Pp. 228-44 in Les espaces protégés: Entre conflits et acceptation, edited by L. Laslaz, C. Gauchon, M. Duval and S. Hétitier. Paris: Belin.

LeMonde.fr. 2015. “Afrique du Sud: une justice impuissante face au braconnage des rhinocéros" ("South Africa's ineffective justice when faced with the poaching of rhinoceroses"). LeMonde.fr. with AFP, 8 October. Retrieved February 5, 2016 (http://www.lemonde.fr/afrique/ article/2015/08/10/afrique-du-sud-une-justice-impuissante-face-au-braconnage-desrhinoceros_4719242_3212.html).

Mathur, Nayanika. 2014. "The Reign of Terror of the Big Cat: Bureaucracy and the Mediation of Social Times in the Indian Himalaya.” Journal of the Royal Anthropological Institute:148-65. 
Mathur, Nayanika. 2016. "The Mark of the Beast: Identifying, Hunting and Conserving Big Cats in India." Working paper presented at the workshop Taking Nature to Court in India, Paris, March 7.

Mawdsley, Emma. 2010. "The Abuse of Religion and Ecology: The Vishva Hindu Parishad and their Dam." Pp. 151-65 in Culture and the Environment in the Himalaya, edited by A. Guneratne. New Delhi: Routledge.

Menon, Manju and Kanchi Kohli. 2016. "Finding a Just Place for Gods: Debates on Culture, Ecology and Economic Growth in Indian Courts." Working paper presented at the workshop Taking Nature to Court in India, Paris, March 7.

Michelot, Agnès. 2006. "Les réserves de biosphère: quelles perspectives pour la gestion des crises environnementales? Le cas du complexe du W du Niger." Pp. 117-30 in Temps et espaces des crises de l'environnement, edited by C. Beck, Y. Luginbühl and T. Muxart. Paris: Éditions Quae.

National Green Tribunal. 2012. Rohit Choudhury vs. Union Of India \& Ors on 7 September, 2012, Retrieved May 15, 2016 (https://indiankanoon.org/doc/103217366/).

Press Trust of India. 2014. "Assam Government Killing Rhinos to Make Way for Bangladeshi Immigrants: Narendra Modi," 1 April. Retrieved May 5, 2015 (http://www.ndtv.com/electionsnews/assam-government-killing-rhinos-to-make-way-for-bangladeshi-immigrants-narendramodi-555757).

Rademacher, Anne M. 2010. "Restoration and Revival: Remembering the Bagmati Civilization." Pp. 166-85 in Culture and the Environment in the Himalaya, edited by A. Guneratne. New Delhi: Routledge.

Rodary, Etienne. 2008. "Les parcs nationaux africains, une crise durable." Pp. 207-26 in Les parcs nationaux dans le monde: Protection, gestion et développement durable, edited by S. Héritier and $\mathrm{L}$. Laslaz. Paris: Ellipses.

Saikia, Arupjyoti. 2005. Jungles, Reserves, Wildlife: A History of Forests in Assam. Guwahati, Assam: Wildlife Areas Development and Welfare Trust.

Saikia, Ritupallab. 2014. "Dispur will start an eviction drive in KNP." The Telegraph, Calcutta, August 28. Retrieved May 5, 2015 (http://www.telegraphindia.com/archives/archive.html).

Sarma, Indrani. 2012. "An Assessment of the Indian Forest Rights Act 2006 in Assam." Journal of Alternative Perspectives in the Social Sciences 4(2):493-517.

Sen, Sarbani. 2015. "The 'Public Interest' in India: Contestation and Confrontation before the Supreme Court.” DIOGENES 60(3-4):27-44.

Sengupta, Nandita. 2014. “Can Kaziranga National Park Combat Rhino Poaching by Going HighTech?” Firstpost.com, 13 August. Retrieved May 5, 2015 (http://www.firstpost.com/india/cankaziranga-national-park-combat-rhino-poaching-by-going-high-tech-1662805.html).

Sharma, Mukul. 2001. "Nature and Nationalism." Frontline, 18(3), February 3-16. Retrieved May 20, 2016 (www.hinduonnet.com/fline/fl1803/18030940.htm).

Sharma, Mukul. 2002. "Saffronising Green." Seminar (New Delhi): Shades of Green: A Symposium on the Changing Contours of Indian Environmentalism, August 2002. Retrieved May 20, 2016 (www.indiaseminar.com/2002/516\%20mukul\%20sharma.htm).

Sharma, Mukul. 2012. Green and Saffron: Hindu Nationalism and Indian Environmental Politics. New Delhi: Permanent Black.

Sivaramakrishnan, Kalyanakrishnan. 2011. "Environment, Law, and Democracy in India.” The Journal of Asian Studies 70(4):905-28. 
Smadja, Joëlle. 2013. "How Environmental Policies Reshape the Himalayan Area: New Environmental Territories, New Environmental Borders-The Example of Kaziranga National Park (Assam)." Pp. 223-45 in Territorial Changes and Territorial Restructurings in the Himalayas, edited by J. Smadja. New Delhi: Adroit Publishers.

Tawa Lama-Rewal, Stéphanie. 2017. “Addressing the Courts, Restoring Citizenship: Public Hearings in India.” SAMAJ 16 (https://samaj.revues.org/4413).

Thakur, Sivasish. 2015a. "Drive-By NGOs to Secure 100 Elephant Corridors." The Assam Tribune, Guwahati, 3 July. Retrieved May 20, 2016 (http://www.assamtribune.com/jul0315/state055.txt).

Thakur, Sivasish. 2015b. "Conviction rate of arrested rhino poachers poor." The Assam Tribune, Guwahati, 30 September. Retrieved May 20, 2016, http://www.assamtribune.com/scripts/ detailsnew.asp?id=sep3015/at057.

The Asian Age, Guwahati. 2013. "Rhino Killings: CBI to Seek Interpol Aid." 9 April. Retrieved May 5, 2015 (http://www.wwfenvis.nic.in/ViewGeneralLatestNews.aspx?format=Print\&Id=1716).

The Assam Tribune, Guwahati. 2010. "President's nod to amendments in Wildlife Act." 20 October 2010. Retrieved May 5, 2015 (http://www.assamtribune.com/scripts/detailsnew.asp?id=oct2010/ at094).

The Assam Tribune, Guwahati. 2014. "Eviction Drive at Kaziranga from Sept. 6." 31 August. Retrieved May 5, 2015 (http://www.assamtribune.com/scripts/detailsnew.asp?id=aug3114/ state056).

The Sentinel, Guwahati. 2014. "HC directs scrutiny of Kaziranga encroachers," November 4, in Assam Green File, Environmental news, Sept $1^{\text {st }}$ to December $31^{\text {st }} 2014$, vol. 1, ENVIS Centre Assam. Retrieved May 5, 2015 (http://asmenvis.nic.in/WriteReadData/UserFiles/file/Assam\% 20Green\%20File.pdf).

Tigernet. 2013a. Tigernet a directory of tigers and other wildlife mortality. "Decline in various forests/national parks", 5 December 2013, Rajya Sabha. Retrieved October 16, 2015 (http:// www.tigernet.nic.in/Alluser/Parliament_Detail.aspx?Parliament_Id=685).

Tigernet. 2013b. Tigernet a directory of tigers and other wildlife mortality. "Wildlife Protection Act, 1972”, 16 December 2013, Lok Sabha. Retrieved October 16, 2015 (http:// www.tigernet.nic.in/Alluser/Parliament_Detail.aspx?Parliament_Id=686).

Tigernet. 2014. Tigernet a directory of tigers and other wildlife mortality. "Assam plan to save rhinos by dehorning stirs. Debate.” The Pioneer, Guwahati, 15 February. Retrieved October 16, 2015. (http://www.tigernet.nic.in/Alluser/News_Detail.aspx?News_Id=2336).

Tigernet. 2015a. Tigernet a directory of tigers and other wildlife mortality. Parliament. Human Animal Conflict. Lok Sabha. 24 February. Retrieved October 16, 2015 (http://www.tigernet.nic.in/ Alluser/Parliament_Detail.aspx?Parliament_Id=735).

Tigernet. 2015b. Tigernet a directory of tigers and other wildlife mortality. Parliament. Schemes for Wild Animals. Lok Sabha. 28 April. Retrieved October 16, 2015 (http://www.tigernet.nic.in/ Alluser/Parliament_Detail.aspx?Parliament_Id=726).

UNESCO. N.d. “Kaziranga National Park. Outstanding Universal Value.” Retrieved July 20, 2016 ( http://whc.unesco.org/en/list/337).

UNESCO. 2008. "State of Conservation, Kaziranga National Park." Retrieved September 10, 2014 ( http://whc.unesco.org/en/soc/814). 
UNESCO. 2011. "State of Conservation, Kaziranga National Park." Retrieved September 10, 2014 ( http://whc.unesco.org/en/soc/814).

Upadhyay, Sanjay, Bhattacharya Prodyut, Kumari Surya and Patnaik Sanjoy. 2009. “Community Forest Resource and Community Forest Rights: Implementation and Institutional Challenges under Forest Rights Act, 2006." A Forest Governance Learning Group India Initiative, November. ELDF, IIFM, CPF, RCDC.

Vaidya, Anand. 2016. “'The Water, Forest, and Land Belong to Us': Caste, Property, and India's Forest Rights Act." Working paper presented at the workshop Taking Nature to Court in India, Paris, March 7.

\section{NOTES}

1. Words logged during a Public Hearing about Kaziranga Eco-Sensitive Zone.

2. It was launched by the Government of India in April 1973.

3. Before this date, only the offended party could appeal to the court for justice to be carried out. On the contrary, Public Interest Litigations permit any bona fide member of the "public" to seek intervention from the court when a matter of "public interest" is at stake. A PIL is directly filed by an individual or group of people (NGO, institution) with the Upper Courts. It may also be filed by the court itself (suo motu). PIL was introduced to protect the disadvantaged and to ensure prompt social justice with the help of the law.

4. The Forest Rights Act 2006 or "The Scheduled Tribes and Other Traditional Forest Dwellers (Recognition of Forest Rights) Act, 2006 (FRA) aims at undoing historic injustice especially towards tribal communities as well as to 'other [bona fide] traditional forest dwellers,' by recognizing those rights which have not been recorded during the reservation process, by securing tenure, and by strengthening the conservation regime through a framework of rights with responsibilities, authority and duties to protect, regenerate and conserve community forest resources." (Upadhyay et al. 2009:9).

5. These claims are based on Appendix 6 to the Indian Constitution which, after Independence of India, was drafted to give administrative autonomy to certain tribal populations registered as Scheduled Tribes.

6. About Misings living in the area surrounding KNP, see Crémin (2014).

7. From 2006 to 2011 within the ANR-funded "Languages, Cultures and Territories in North-East India" program (ANR-06-BLAN-0131-01), and from 2008 to 2013 within the ANR-funded "Justice and Governance in India and South Asia" (Just-India) program, (ANR 08-GOUV-064). All the stakeholders in these conflicts were interviewed during fieldwork: the population surrounding the Park and within the Park ("encroachers"), the population suffering from damage due to wildlife, petitioners, journalists, lawyers, NGO members, activists, administrative staff (forest, park), poachers, etc. I also had access to several petitions and case reports and was lucky enough to go to Golaghat District Court to attend some trials, even though they were not directly related to the cases mentioned here.

8. Translated from the French.

9. Between 1995 and 2005, 62 individuals and 56 elephants were killed, 857 houses were destroyed along with hundreds of hectares of crops in Golaghat district alone (Di Fonzo 2007). In the whole of Assam, 567 rhinoceroses were slaughtered between 1980 and 2005, while 209 people were killed by elephants between 2005 and 2009 (70 in 2009) and 60 elephants were slain (42 in 2009). Between April 2008 and March 2009, 171 domestic animals (for the most part cows and bullocks) were killed by tigers on farms around Kaziranga (Bora et al. 2009).

10. Indian Rupees (INR) $100=$ USD 1.5. 
11. With a Core Area including Kaziranga National Park and the $1^{\text {st }}, 2^{\text {nd }}, 3^{\text {rd }}$ and $5^{\text {th }}$ Additions which total $482 \mathrm{~km}^{2}$ and a buffer zone of $573 \mathrm{~km}^{2}$ comprising the $4^{\text {th }}$ and $6^{\text {th }}$ additions and two reserve forests and two sanctuaries.

12. Numaligarh Refinery is a joint venture between Bharat Petroleum, Oil India and the Assam Government. Set up in 1996 not far from Kaziranga, it was accepted by the central Ministry of Environment and Forests on condition that, since it is likely to cause pressure on the natural resources and the wildlife habitat in Kaziranga National Park and its surroundings, a "No Development Zone" be created within a $15-\mathrm{km}$ radius of the said refinery.

13. As Kumar and Kerr recall: "Forests are defined in a purely legalistic manner in India, as areas that have been converted to forest through [the] application of various laws. Thus, pastoral landscapes and areas that are regularly covered in snow, as well as deserts, have been classified as 'forest.' The Supreme Court in 1996 defined 'forest' as including the dictionary definition of the word as well as all areas that have been classified as forestland under any law (Dutta and Yadav 2005). We use the term 'forest dwellers' to refer to the category of people who live on, or whose livelihoods depend on, land legally classified as forest" (Kumar and Kerr 2012:753).

14. The Krishak Mukti Sangram Samiti is gaining influence in the area and an increasing number of farmers now belong to it. It is headed by Akhil Gogoi, a charismatic activist, who adheres to Anna Hazare's anti-corruption precepts. He advocates the use of the Right To Information (RTI) Act, 2005, as a tool against corruption and it is indeed being used more and more. In their fight and in the numerous demonstrations they organize, KMSS activists put to the fore the Forest Rights Act 2006 to demand farmers' rights, even though most of the farmers around Kaziranga I talked to and who belong to KMSS were not aware of this right.

15. This is exactly what Sanjay Upadhyay-an advocate at the Supreme Court in Delhi and specialist in Environmental Law who took part in drafting the Forest Rights Act 2006-explained to me (personal communication).

16. See note 13.

17. Campaign for Survival and Dignity is an organization that worked on the implementation of the Forest Rights Act 2006.

18. Narendra Modi has been the Prime Minister of India since May 2014 when his party, the BJP, won the national elections.

19. Since January 2014 in India the Right to Fair Compensation and Transparency in Land Acquisition, Rehabilitation and Resettlements Act, 2013, has replaced the Land Acquisition Act of 1894. They both concern (Central and State) governments' acquisition of private land for the purpose of industrialization, the development of infrastructural facilities or the urbanization of private land. However, in December 2014, the President of India tried to modify it given "the development needs of the country." The bill was rejected by Rajya Sabha.

20. Emphasis mine.

21. BJP: The Bharatiya Janata Party (Indian People's Party) is a Hindu nationalist right-wing party. This is the current Prime Minister of India Narendra Modi's party.

22. Even though the Assamese Chief Minister at the time (Tarun Gogoi) belonged to the Indian National Congress, as a result of these elections BJP became the first party in Assam with 50 per cent of the votes and seven positions out of fourteen at Lokh Sabha. In June 2016 it won the majority in the State elections.

23. Hindu Yuva Chatra Parishad: Association for Young Hindu Students, which is sympathetic to the BJP's cause.

24. Model villages, called Adarsh Grams, are part of a rural development program, Sansad Adarsh Gram Yojana (SAGY) which the Indian Prime Minister, Narendra Modi, launched in October 2014. Under this scheme each Member of Parliament has both to choose in their constituency a village other than their own and their in-laws' which they are to represent, and to take charge of developing physical and institutional infrastructures in this village in order to turn it into a 
model village by 2016. Before this project was launched, numerous model village projects had come into being through work carried out by panchayats, governments or NGOs. They all aimed at improving villagers' livelihoods, infrastructures and services.

25. On Public Hearings, see Stéphanie Tawa Lama-Rewal's text in this volume (https:// samaj.revues.org/4413).

26. Chaat Puja is a Hindu festival that takes place in October or November and which is observed by Assamese, Biharis, Nepalis, etc. It includes bathing in the river and pujas (offerings) from the riverbank that, before the creation of Kaziranga National Park, used to be performed on the south bank of the Difaloo river.

27. Garu Bihu is the first day of Rongali Bihu, which is an important festival for Assamese people in mid-April: it celebrates the Assamese New Year and harvesting. Uruka is the eve of this first day.

28. Which stipulates: "the Tribunal shall have jurisdiction over all civil cases where a key question about the environment (including enforcement of any legal right relating to the environment) is involved and such a question arises out of the implementation of the enactments specified in Schedule I."

29. Under section 38 IV B of the Wildlife (Protection) Act 1972.

30. Under section 38 IV C of the Wildlife (Protection) Act 1972 .

31. Translated from the French.

32. Translated from the French.

33. National election at Lokh Sabha, which put the BJP at the head of the Indian State, with Narendra Modi as its Prime Minister.

34. Assam Peoples Association is a regionalist and nationalist political party in Assam and is closely linked to the BJP.

35. With which Assam, which has well-known autonomist movements, does not maintain close ties; besides the Assamese speak the Assamese language, not Hindi.

36. Translated from the French.

37. Translated from the French.

38. Translated from the French.

\section{ABSTRACTS}

This text is based on an analysis of conflicts concerning Kaziranga National Park in Assam. Famous for the one-horned rhinoceros, this Park has become a political arena where tension has been mounting since its 2007 inclusion in a project aimed at protecting tigers. The physical injury and damage caused by wildlife to people and their property (land, animals, houses), the eviction of populations from within the Park's perimeter, and poaching have led to conflicts that combine ecological, social, political, cultural and symbolic features, and which are being brought more and more often before the law courts. The aim of this paper is to show how these features are utilized by the different protagonists and how, since 2006, new decision-making bodies with extensive powers, environmental legislation, and nature-protection or population-defense organizations have contributed to defining the forms these conflicts have taken. Through the lens of environmental law in the making, it highlights some of the workings of India's nature protection policy. The Kaziranga example provides an overview of the problems key measures or 
laws have created in the field of environmental protection, whether it is a question of them being applied too rigidly-as is the case of the Wildlife (Protection) Act 1972-, of them being bent-this is the case of Public Interest Litigations the original purpose of which has completely changed-, or of them not being applied at all-which is the case of the Forest Rights Act 2006 in Assam.

INDEX

Keywords: environmental law, Wildlife (protection) Act 1972, Public Interest Litigation, Forest Rights Act 2006, Tiger Project, rhinoceros, Kaziranga National Park, Assam

\section{AUTHOR}

JOËLLE SMADJA

Research Fellow, CNRS (French National Center for Scientific Research), Center for Himalayan Studies 